\title{
COPYRIGHT LAW AND THE FREEDOM OF PANORAMA: THE RIGHT TO COMMERCIALISE PHOTOGRAPHS OF PROTECTED WORKS
}

\author{
A dissertation submitted to \\ Victoria University of Wellington \\ in fulfillment of the requirements for the degree of \\ Master of Laws
}

Faculty of Law

Victoria University of Wellington 2014 



\section{Acknowledgement}

The process of writing this dissertation has been one of the most significant academic challenges I have ever had to face, and it feels like a dream to finally complete this chapter of my life. Without the support, patience, and guidance of the following people, this dissertation would not have been completed. It is to them that I owe my deepest gratitude.

- AProf Susan Corbett, who undertook to act as my supervisor despite her many other academic and professional commitments. Her patience, wisdom, knowledge, and commitment to the highest standards inspired and motivated me.

- My family - Sudjono Barak Rimba, Hananto P Sudharto, Ratnaningsih Barak Rimba, Nina Maudinia Herangi Sudiono-Price, and Rachel Puteri Zakaria. Without them, this effort would have been worth nothing.

- My seminar advisor - Zane Te Wiremu Jarvis, "Welly buddies" - Andre Simangunsong, Ann Heimbrodt, Frenky Simanjuntak, Hizkia Respatiadi, Pedro Ramirez, Tran Ngoc Diep, Ubaidillah Nugraha, William Robertson, and all of my friends in Jakarta for their sincere encouragement and inspiration throughout my research work and lifting me uphill this phase of life.

This dissertation is dedicated to Sudjono Barak Rimba, and to all my family. 


\section{Abstract}

Making an unauthorised copy of a copyright-protected work is a copyright infringement, as is making an adaptation or a derivative work without gaining prior consent from the author or authors of the copyright-protected work. It was once questioned at one of the Berne Convention amendment meetings whether to take photographs of copyright-protected literary works was to make copies of them. The meeting concluded that taking photographs of literary works meant making copies of them, and, therefore, photographs should not be taken without gaining the prior consent of the author or authors. However, there was no discussion about photographs of other type of works, such as buildings and sculptures. Taking photographs of architectural and sculptural works permanently situated in public places is protected under "freedom of panorama", a provision of copyright laws that permits the taking of photographs of those works, which is applied differently in some countries. This paper discusses copyright protection for those photographs, though there are not many cases available in this issue as the terminology of "freedom of panorama" was only recently coined. The discussion is based on the Berne Convention, and copyright law in the United States, New Zealand, and Indonesia. Freedom of panorama may seem to limit the exclusive rights for architects and sculptors to authorise any acts to be done over their works. However, photographers also have the need to be sure that their photographs are protected, including photographs that are taken under the freedom of panorama. Therefore, this paper argues that the photographers who take photographs under the freedom of panorama should be able to exercise exclusive and moral rights over their photographs. Although the three countries mentioned provide protection for the "freedom of panorama", it is protected differently and, therefore, there is a need to include the freedom of panorama in an international copyright treaty to avoid a possible conflict of laws. 


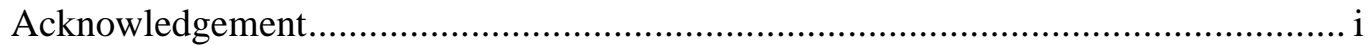

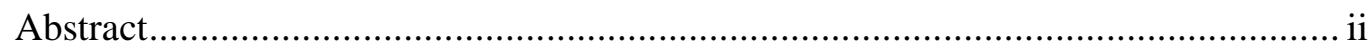

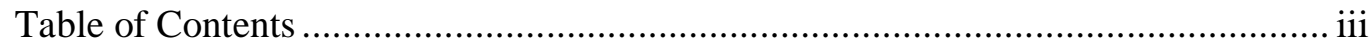

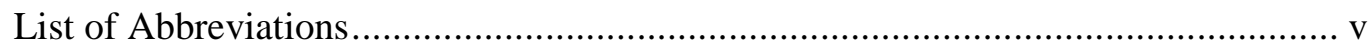

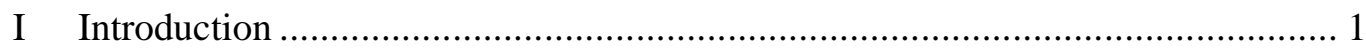

A A Possible Limit to Exclusive Rights and Moral Rights for Architects and Sculptors .............................................................................................. 3

B Issues with the Freedom of Panorama ..................................................... 6

II History of Copyright Protection for Photographic, Architectural, and Sculptural

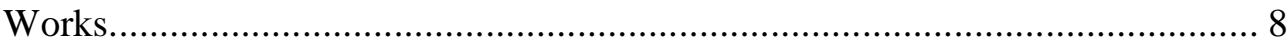

A History of Copyright Protection for Photographic Works........................... 9

1 Berne Convention for the Protection of Literary and Artistic Works of

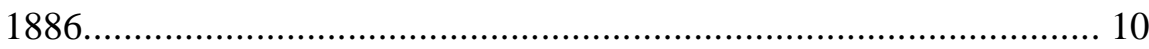

2 Additional Act Amending Articles 2, 3, 5, 7, 12, and 20, of the

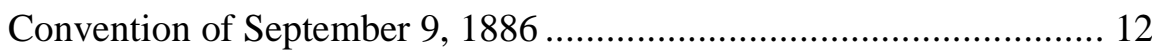

3 Revised Berne Convention for the Protection of Literary and Artistic Works of 1908 ............................................................................... 13

4 International Convention for the Protection of Literary and Artistic

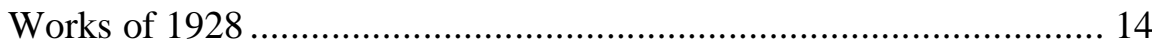

5 Berne Convention for the Protection of Literary and Artistic Works of

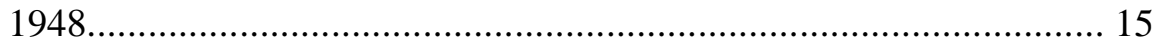

6 Berne Convention for the Protection of Literary and Artistic Works of

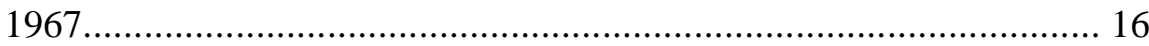

7 Berne Convention for the Protection of Literary and Artistic Works of

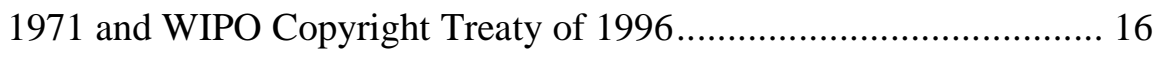

8 Copyright Protection for Photographs of Copyright-Protected Works . 17

B History of Copyright Protection for Architectural and Sculptural Works... 19

1 Architectural Works.................................................................... 19

2 Sculptural Works ..................................................................... 20

III Jurisdictional Comparison of Copyright Laws ................................................ 21

A Overview of the Freedom of Panorama Provisions Internationally ............ 21

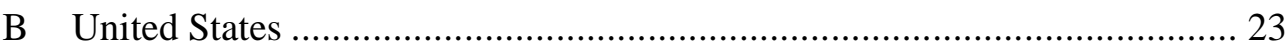

1 Exclusive Rights ........................................................................... 23

2 Freedom of Panorama ...................................................................... 24

3 Moral Rights in the Freedom of Panorama ...................................... 26

4 Economic Rights in the Freedom of Panorama................................... 28

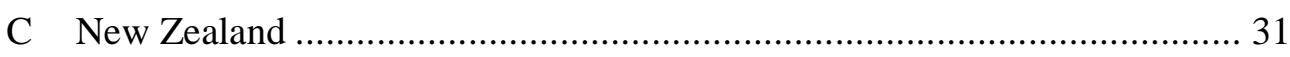

1 Exclusive Rights ..................................................................... 31 
2 Freedom of Panorama ................................................................ 32

3 Moral Rights in the Freedom of Panorama ......................................... 34

4 Economic Rights in the Freedom of Panorama................................... 36

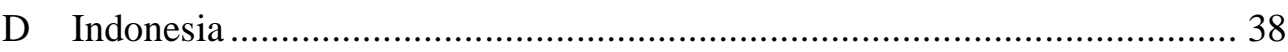

1 Exclusive Rights ........................................................................... 38

2 Unauthorised Use of Copyright-Protected Works and the Freedom of Panorama .......................................................................... 38

3 Protection of Moral Rights .......................................................... 40

4 Protection of Economic Rights.................................................... 42

E Conclusion on the Jurisdictional Comparison........................................... 43

IV Comparison to Photographs of "Public Domain Works" ................................. 44

A Adaptation or Derivative Works of Public Domain Works ....................... 45

B Copyright Protection for Photographs of Public Domain Works ............... 46

C Comparison to Photographs and the Freedom of Panorama....................... 51

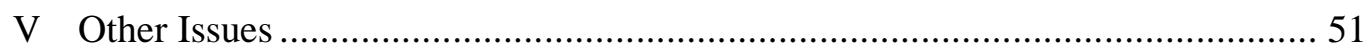

A Conflict of Laws ................................................................................... 52

1 Country of Origin of Works ...................................................... 53

2 Hypothetical Case ..................................................................... 57

B International Recognition and Protection for Photographs Taken under the

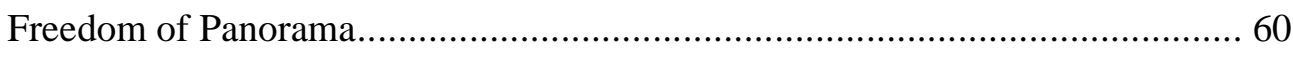

C Fair Practice and the Freedom of Panorama ........................................... 61

1 Fair Practice Provisions in Berne Convention and Its Amendments..... 61

2 Fair Practice in Several Countries .................................................. 62

3 Fair Practice and Photographs of Copyright-Protected Works ............ 64

D No Exceptions or Limitations to Moral Rights of Architects and Sculptors 64

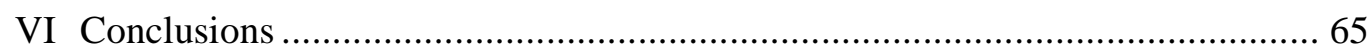

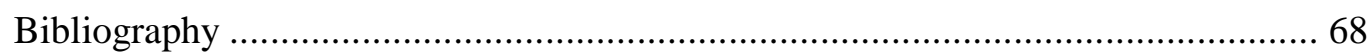




\section{List of Abbreviations}

Berlin Act (1908) Revised Berne Convention for the Protection of Literary and Artistic Works of 1908

Berne Convention (1886) Berne Convention for the Protection of Literary and Artistic Works of 1886

Brussels Act (1948)

Berne Convention for the Protection of Literary and Artistic Works of 1948

Paris Act (1971)

Berne Convention for the Protection of Literary and Artistic Works of 1971

Paris Additional Act (1896)

Additional Act Amending Articles 2, 3, 5, 7, 12, and 20, of the Convention of September 9, 1886

Rome Act (1928)

International Convention for the Protection of Literary and Artistic Works of 1928

Stockholm Act (1967) Berne Convention for the Protection of Literary and Artistic Works of 1967 



\section{Introduction}

As the world of photography and tourism becomes more popular, it is inevitable that tourists and others will wish to take photographs of the places they have been to, including photographs of buildings and sculptures that are permanently situated in public places. The "freedom of panorama" makes it possible for others to take photographs of copyright-protected buildings and sculptures without having to gain prior permission from their architects and sculptors. The act of taking those photographs is not considered to infringe copyright. Newell, with reference to the term "panoramafreiheit" based on German copyright law, argued that "the freedom of panorama" as "the right to take photographs of public spaces ${ }^{2}$ and use such photographs for personal or commercial purposes". 3

Newell limited the discussion of the freedom of panorama to be more focused on copyright law in the United States that only allows people to make pictorial representations of architectural works, which he thought as a "very narrow view in its approach to freedom of panorama in comparison to many other jurisdictions". ${ }^{\mathrm{He}}$ then argued that the same provision should also apply to sculptural works. This paper examines whether the freedom of panorama equates to the freedom to photograph copyright-protected works, such as buildings and sculptures permanently situated in public places, without the prior consent of the authors of those works. This paper also discusses whether it is possible for photographers to gain commercial advantage from those photographs under copyright law.

The freedom of panorama only directly relates to architectural and sculptural works that are still protected by copyright and are permanently situated in public places, as there is no question about prohibition to take photographs of copyright-protected works in controlled spaces such as museums and exhibition halls without its copyright holders' permission, or the freedom to take photographs of works that are already in the public domain. Despite the fact that the freedom is exercised in several countries including the United States and New Zealand ${ }^{5}$, recognition that the freedom of panorama provides copyright protection for photographic works still depends on

\footnotetext{
${ }^{1}$ Bryce Clayton Newell "Freedom of Panorama: A Comparative Look at International Restrictions on Public Photography" (2011) 44 Creighton L Rev 405.

${ }^{2}$ Newell does not define the meaning of "public spaces" and there is no reference of this term in Title 17 USC. To compare to New Zealand Copyright Law 1994, the terms being used in art 73(1)(b) are "public places" and "premises open to the public".

${ }^{3}$ Newell, above n 1, at 405-406 (footnote added).

${ }^{4}$ At 406.

${ }^{5}$ For example, the freedom to photograph architectural works is mentioned in the United States of America through Copyright Law Title 17 USC § 120(a) and in New Zealand through the Copyright Act 1994, s 73.
} 
national copyright laws, and there are no provisions that mention it in any international treaties regarding copyright protection, including the Berne Convention.

The term of "the freedom of panorama" that was coined by Newell actually includes three legal issues. The first issue is related to the exclusive rights that exist over architectural and sculptural works. Architects and sculptors are entitled to exclusive rights over their work, and that includes the right to authorise the making of a copy, adaptation or derivative work. If taking photographs of architectural and sculptural works is considered to be copying, then the taking of them without the prior consent of the authors of those works would be an act of copyright infringement. However, taking such photographs for personal use or under fair use reasoning might not necessarily offend the author's exclusive rights. Therefore, the first issue is closely related to the second issue of using such photographs for commercial purposes.

Exclusive rights held by the authors of copyright-protected works include the rights to gain commercial advantage from them, or the economic rights to the work. Taking photographs of architectural and sculptural works protected by copyright without gaining prior consent should not be a legal issue so long as the photographs are taken under the freedom of panorama and for personal use only. ${ }^{6}$ However, when a photographer would like to gain exclusive rights to such photographs or, at least, would like to be able to commercialise them, a conflict with the architects and sculptors' exclusive rights arises.

The third issue is related to moral rights over the photographs of architectural and sculptural works. Moral rights are given to an author of a work as an acknowledgement that he or she made the work. ${ }^{7}$ If a photographer gained moral rights over a photograph, he or she would also be granted exclusive rights over it, and, therefore, the photographs would be protected by copyright in the same way as other photographic works.

\footnotetext{
${ }^{6}$ New Zealand Copyright Act 1994 acknowledges that personal use of copyright-protected works is not copyright infringement, and it is limited to the act of copying sound recordings under art 81A of the Act. Private uses of copyright material are also allowed under the Act, with some limitations under art 43 of the Act including prohibition to make more than one copy of the same work. Undang-Undang tentang Hak Cipta 2002 (Indonesia) [Indonesian Copyright Law 2002] also allows personal use in art 15 of the Law including to make of a copy of a computer program for the owner's personal use. Though it is also recognised in the United States, the United States statute does not provide a provision for lawful personal use.

7 Berne Convention for the Protection of Literary and Artistic Works (opened for signature 9 September 1886, last amended 24 July 1971, entry into force 15 December 1972) [Paris Act 1971], art 6bis (1).
} 
For the purpose of this paper, "freedom of panorama" only refers to the right to photograph architectural and sculptural works without gaining prior consent from the authors of those works, in line with provisions in the Berne Convention for the Protection of Literary and Artistic Works, and copyright law in the United States, New Zealand, and Indonesia. The issues related to whether the authors of such photographs should be able to exercise exclusive and moral rights will be answered by looking at the copyright laws in those countries.

Copyright protection for photographic works within the Berne Convention is firstly believed to be limited to photographs with "original" based on copyright-protected works. ${ }^{9}$ The second condition of the protection may also mean that photographs of buildings and sculptures taken under the freedom of panorama are not protected under the Berne Convention, because the objects of the photographs are based on something already protected under copyright. However, as the Berne Convention has never set a clear limit on which type of photographs are protected under the Convention, it would then lead to the question whether the freedom of panorama should be included in the Berne Convention, as that freedom is already protected in several countries.

\section{A A Possible Limit to Exclusive Rights and Moral Rights for Architects and Sculptors}

Though Newell did not elaborate more on the meaning of "freedom" in the freedom of panorama, the word "freedom" should refer to the ability to act under the law which related to taking photographs, and this freedom is closely related to the right to freedom of expression. Though art 19 of the Universal Declaration of Human Rights only explicitly mentioned that "the right to freedom of ... expression includes freedom to hold opinions without interference" $" 10$, the freedom of expression is not limited to such explanation and also not limited to expression through writing or speech.

\footnotetext{
${ }^{8}$ Newell, above $\mathrm{n} 1$, at 410 . Original means that the works were made not based on other copyrightprotected works. See also Stephen $\mathrm{P}$ Ladas The International Protection of Literary and Artistic Property (The Macmillan Company, New York, 1938) vol 1 at 231 and Sam Ricketson and Jane C Ginsburg International Copyright and Neighbouring Rights: The Berne Convention and Beyond (Oxford University Press, Oxford, 2006) vol 1 at 482.

9 "Records of the Diplomatic Conference: Convened in Berlin, October 14 to November 14, 1908" in Sam Ricketson and Jane C Ginsburg International Copyright and Neighbouring Rights: The Berne Convention and Beyond (9 December 2005) Oxford University Press <http://global.oup.com> (Records of the Berlin Conference of 1908).

${ }^{10}$ The Universal Declaration of Human Rights, art 19.
} 
Related to the freedom of expression, copyright law was established based on the thought that expressed creativity should be protected under the law. The freedom of panorama should be defined as the freedom to photographs anything in public places including copyright-protected works, because it is difficult to put a boundary in public places and to ensure that people do not offend the law by taking photographs of public places. Public places do not belong to anyone, but photographs, under certain categories, are protected as works of art of the photographers and are protected under copyright law. This protection should be made clearly so that the photographers are protected and their creativity is not limited by others.

As this discussion will include the effort to determine exceptions and limitations related to copyright protection, then it will be appropriate to also take the three-step test to Berne Convention into account. The three-step test is a clause that establishes three cumulative conditions to the limitations and exceptions of a copyright holder's rights, used legal parameters for reproducing a work. ${ }^{11}$ The limitation for a person's freedom or rights under the law lies on other person's freedom or rights. If an act, when taken, could be violating other person's freedom, then such act should be considered as off-limit. The same logic should apply for the recognition of the freedom of panorama. If the applicability of this freedom could violate other person's freedom, for example the freedom for architects and sculptors to create any form of derivative works from their works, then this freedom should not be applied. However, in the same sense of this logic, if the law should not see the applicability of this freedom as violating architects and sculptors' rights, then this freedom should be applicable when necessary.

Although recognition of the freedom of panorama could be considered as a development of current copyright protection for photographic works, ${ }^{12}$ it would not be easy to conclude that this freedom should be protected. On the one hand, protecting photographs taken under freedom of panorama could lead to some legal and ethical problems in relation to copyright protection of the objects of the photographs. Protecting the photographs may be in conflict with the moral rights of the authors of the depicted copyright-protected works and also their rights to gain commercial advantage from those works. That is because taking photographs of copyrightprotected works may be considered to be making copies of the works, and publishing

11 Roger Knights "Limitations and Exceptions under the "Three-Step-Test" and in National Legislation-Differences between the Analog and Digital Environment" in World Trade Organization Regional Workshop on Copyright and Related Rights in the Information Age (Moscow, 2001).

${ }^{12}$ Recognition for copyright protection over photographs taken under the freedom of panorama would mean that there is no "grey area" that such photographs are original works and therefore the photographers are entitled for exclusive rights and moral rights over such photographs, while currently there is no internationally-recognised criteria to determine whether a photograph is original or not. 
such photographs may be considered equal to the act of reproducing them ${ }^{13}$, which would logically require prior consent from the authors or copyright owners ${ }^{14}$ of the works to authorise those acts. Doing such acts without gaining consent from the authors of the copyright-protected works would violate the copyright owners' exclusive rights over the works, not to mention violate the authors' moral right to be acknowledged as the authors of the works if the published copies fail to give them proper attribution.

On the other hand, taking photographs of copyright-protected works might also be considered as making adaptation of the works, ${ }^{15}$ which will result in the making of another artistic work based on copyright-protected works. ${ }^{16}$ If that is the case, under the freedom of panorama, a photographer would be able to gain commercial advantage from a photograph of a building, although he might not be considered to be the sole author of the photograph because the photograph was based on another person's work. However, it would also mean that other people may be able to gain commercial advantage from a copyright-protected work, and that would eventually defeat the purpose of protecting the author's exclusive rights for his copyrightprotected work.

The professional photographers who put their efforts into producing photographs of copyright-protected architectural and sculptural works would like to exercise their right to gain commercial advantage and to publish those photographs and to have that right protected, to be acknowledged as the author of their works, and to have the right to convert the photographs into various mediums such as posters. ${ }^{17}$ Protecting those photographers' rights to do that may violate the architects and the sculptors' rights to be acknowledged as the authors of the works depicted—for example in New Zealand.

13 Berne Convention for the Protection of Literary and Artistic Works (opened for signature 9 September 1886, last amended 24 July 1971, entry into force 15 December 1972) [Paris Act 1971], art 9.

${ }^{14}$ As the exclusive rights attached to copyright may be transferred to other people authorised by the authors, although it is not mentioned in the Berne Convention, some copyright laws mentioned different definition for authors and copyright owners/holders. For example, Art 1 of the Indonesian Copyright Law 2002 defines an author as "person or several persons jointly upon whose inspiration a Work is produced, based on the intellectual ability, imagination, dexterity, skill or expertise manifested in a distinctive form and is of a personal nature" and copyright holder as "the Author as the Owner of the Copyright, or any person who receives the right from the Author, or any other person who subsequently receives the right from the aforesaid person".

${ }^{15}$ The act of making a new artistic work based on a copyright-protected work is called making an "adaptation" according to New Zealand Copyright Act 1994, while it is called making a "derivative work" according to Title 17 USC and it has the same meaning as "derivative work" under the Indonesian Copyright Law 2002. See Copyright Act 1994, s 92, Copyright Act 17 USC $\S 101$ and 103, and Indonesian Copyright Law 2002, art 12(1)(1).

${ }^{16}$ Paris Act 1971, art 12.

${ }^{17}$ A case related to this issue is The Rock and Roll Hall of Fame and Museum, Inc, et al v Gentile Productions, et al, which will be further discussed in Chapter III. 
It also may violate their rights to object to "derogatory treatment" defeat the purpose of copyright to "prevent the taking of the expression"19, as well. This paper starts with the question: should photographs taken under the freedom of panorama enjoy the same protection as original artistic works, which are protected in the Berne Convention?

\section{B Issues with the Freedom of Panorama}

This paper consists of three main sections. The first section addresses how copyright protection is given to photographic, architectural, and sculptural works as a part of the history of protection. It includes the reason why each of those types of works were protected, the arguments and debates on which the provisions written to protect their copyright were based, and to what extent the those provisions protect the authors of those works. The paper then continues to analyse the legal basis for the right to photograph copyright-protected works that are that are permanently situated in public places in the United States, New Zealand, or Indonesia, and whether the freedom of panorama is protected under the copyright laws of those countries. The discussion then goes on to answer the question of whether the freedom of panorama should be seen as limiting the copyright held by architects and sculptors whose works are photographed, or whether it should be seen as creating new artistic works, and that, therefore, the photographers should gain the same exclusive rights and moral rights as the architects and the sculptors have gained. The third and final section lays out discussion about other issues that may arise because of the protection afforded to photographs taken under the freedom of panorama, and also what may happen if the freedom of panorama is considered to be an act of copyright infringement.

Part II of this paper first looks at the history of copyright protection for photographic works, in order to explain the basic protections afforded to photographic works under the Berne Convention (1886) and its amendments until the enforcement of the Paris Act (1971). It then examines why photographic works are protected under the Paris Act (1971), what kind of photographic works are protected, and why the protection afforded to the authors of photographic works are different to those afforded to the authors of other artistic works under the Paris Act (1971). After a discussion about the protections afforded to photographic works, the paper looks at to what extent that architectural and sculptural works are protected.

\footnotetext{
${ }^{18}$ Copyright Act 1994, s 98.

${ }^{19}$ Susy Frankel Intellectual Property in New Zealand (2nd ed, LexisNexis, Wellington, 2011) at 5.6.3.
} 
Part III presents discussions about the possibility of protecting photographs taken under the freedom of panorama while at the same time protecting the copyright of architects and sculptors'. The arguments will look at examples from three countries, which are the United States, New Zealand, and Indonesia. One the one hand, copyright laws in the United States and New Zealand provide provisions that are in line with the definition of the freedom of panorama, which was coined by Newell, but the meaning of freedom of panorama is more limited in the United States than in New Zealand. According to cases in both countries, commercialising photographs taken under the freedom of panorama may be possible. The architects or the sculptors of the depicted works do not necessarily obtain protection for moral rights on the pictorial representation of their works. On the other hand, the Indonesian Copyright Law 2002 does not provide a clear provision stating whether the freedom of panorama is allowed or prohibited and therefore a different approach would have to be taken to determine the legality of taking photographs of architectural and sculptural works in public places in Indonesia. This part of this paper also provides the provisions regarding the protection to exercise exclusive rights, freedom of panorama, moral rights, and economic rights based on the provisions in the copyright laws in the United States, New Zealand, and Indonesia.

Part IV compares copyright protection for photographs taken under the freedom of panorama to copyright protection for photographs of "public domain works". The arguments provided in this part of this paper would make a point about how photographs of artistic works should be protected under copyright. It argues that the act of taking photograph of artistic works should not be seen as copyright infringement because taking photographs does not affect the ability of the copyright owners of the depicted works to exercise their rights over the works.

Part V presents other issues that may arise or that are already debated in some countries regarding copyright protection for photographs taken under the freedom of panorama. That debate includes the possibility of conflict of laws, limitations and exceptions for the use of photographs taken under the freedom of panorama, and also limitations and exceptions to the exclusive rights held by architects and sculptors. Finally, the paper argues that taking photographs of copyright-protected works located in public places should be allowed and that copyright protection for photographs taken under the freedom of panorama should be explicitly mentioned in the Berne Convention to avoid ambiguity about its provisions and to avoid different protections in "the countries of the Union". ${ }^{20}$ The paper argues that photographers

\footnotetext{
${ }^{20}$ Paris Act 1971, art 1. The member states of the Berne Convention are called "a Union for the protection of the rights of authors in their literary and artistic works".
} 
should be able to gain protection for the exclusive rights over such photographs as well as the right to be acknowledged as the authors of the photographs.

The freedom of panorama discussed in this paper only focuses on its effect on photographic works, and not to other graphic representations of copyright-protected works. Copyright law in the United States only protects the freedom of panorama for pictorial representations of architectural works. ${ }^{21}$ The New Zealand Copyright Act 1994 provides a wider protection for the freedom of panorama, not limited to photographic works but also in relation to architectural works. ${ }^{22}$ It is only fair to compare copyright laws in the United States and New Zealand for similar provisions and therefore this paper limits its discussion to the freedom of panorama and photographic works.

\section{History of Copyright Protection for Photographic, Architectural, and Sculptural Works}

This paper focuses on the protection for photographs of architectural and sculptural works. Therefore, it is necessary to take a look at how these types of works are protected under the Berne Convention and its amendments, including the arguments and considerations behind the protection. This part of this paper also searches for the possibility of implied provisions under the Berne Convention regarding the protection of the freedom of panorama. The explanations about copyright protection for photographic works will be slightly longer than explanations about other works, because architectural and sculptural works have been protected since the enactment of the original text of the Berne Convention. There have been no questions about whether there should be copyright protection for architectural works and sculptural works as both are recognised as artistic works. However, the provision related to their protection still went through some changes, such as the determination as to which national laws should prevail to protect the copyright. For the purpose of talking about the history of the Berne Convention amendments, in this chapter only each amendment is followed by the year of its enactment and the current Berne Convention is called the Paris Act (1971).

Before discussing the recognition of the freedom of panorama, it is important to look at how photographic works finally became a part of literary and artistic works and

\footnotetext{
${ }^{21}$ Copyright Act 17 USC $\$ 120(a)$.

${ }^{22}$ Copyright Act 1994, s 73. It provides protection for graphic work, photograph or film, and visual image of buildings, sculptures, models for buildings, or works of artistic craftsmanship that are permanently situated in a public place.
} 
which forms of copyright are now protected under art 2(1) of the Paris Act (1971). ${ }^{23}$ Copyright protection for literary and artistic works was discussed at various international conferences, but it was not until 1948 that photographs were included in an amendment of the Berne Convention (1886) by the Brussels Act (1948) as artistic works. The amendment of art 2(1) in the Brussels Act (1948) finally allowed the copyright owners of photographs to enjoy moral rights and economic rights. ${ }^{24}$ This protection is given to photographs based on the originality of the photographic works, ${ }^{25}$ and provision remains in art 2 of the Paris Act (1971).

Although protection for photographic works was also provided for in the original text of the Berne Convention, the protection given was different to how photographic works are protected now. The change occurred as photographic works began to be considered as artistic works, although they had not previously been recognised as artworks in several countries. ${ }^{26}$ The first part of this paper explains the changes to copyright protection for photographic works, explains which type of photographs are protected under the Berne Convention, and examines whether photographs taken under the freedom of panorama fit the requirements to be protected by the Berne Convention or whether such photographs have been implicitly protected.

\section{A History of Copyright Protection for Photographic Works}

Although the Berne Convention (1886) has offered protection for various literary and artistic works since 1886, general protection for photographs was not included in the original text of the convention because they were not considered to be a form of artistic work in European Union countries. However, photographs of copyrightprotected artistic works were protected in the Berne Convention of 1886, as stated in the Final Protocol no. 1 of the Berne Convention. In the Final Protocol it was provided that photographs of copyright-protected works should be authorised by the authors of the works in respect of their exclusive rights over the works and "within the limits of private agreements between those who have legal rights". ${ }^{27}$ Therefore, the protection was given to "authorised photographs of copyright-protected works" 28 ,

\footnotetext{
${ }^{23}$ In relation to the chosen countries to compare their copyright laws and its provisions related to the freedom of panorama, it is also important to know that the United States and Indonesia are some of the parties to the Paris Act (1971). New Zealand has the Rome Act (1928) entered into force but afterwards it has only signed the Brussels Act (1948) without submitting the required instrument to enter the Brussels Act (1948) into force in New Zealand.

${ }^{24}$ Berne Convention for the Protection of Literary and Artistic Works (opened for signature 9 September 1886, last amended 26 June 1948) [Brussels Act 1948], art 2(1).

${ }^{25}$ Ricketson and Ginsburg, above n 8, at 444.

${ }^{26}$ Ladas, above n 8, at 227.

27 Berne Convention for the Protection of Literary and Artistic Works (opened for signature 9 September 1886, completed 4 May 1896) [Berne Convention], Final Protocol no 1.

${ }^{28}$ Final Protocol no 1.
} 
before photographs were recognised and protected as artistic works by the Berne Convention.

The Berne Convention for the Protection of Literary and Artistic Works has been amended several times, with each amendment adding a different provision concerning copyright protection for photographic works. The first changes to the Berne Convention of 1886 were made in the Paris Additional Act (1896), where a step towards an obligation to protect copyright for photographs was made. The Paris Additional Act (1896) was revised by the Berlin Act (1908), which was then revised by the Rome Act (1928). Significant progress in protecting photographic works as artistic works was then made in the Brussels Act (1948) and a change in term of protection for photographic works was made in the Stockholm Act (1967). The changes that were made are now applicable through the Paris Act (1971) in 166 countries. $^{29}$

Different provisions aimed at protecting photographic works were made based on the arguments made by the countries of the Union. Early on, the works were not even recognised as artistic works, and therefore could not be protected under the Berne Convention (1886) or the Paris Additional Act (1896). Discussions about the protection of photographic works also concerned themselves whether photographs of copyright-protected works should be allowed and whether the copyright of those photographs should be protected. ${ }^{30}$ Nevertheless, it was not specifically mentioned whether photographs of copyright-protected works were excluded from the definition of protected photographic works under the Paris Act (1971).

\section{Berne Convention for the Protection of Literary and Artistic Works of 1886}

Prior to the completion of the first text of the Berne Convention in 1886, delegates at the 1886 Paris Conference started the debate about whether photographic works should be added to the list of literary and artistic works protected by the Berne Convention. The delegations that participated in the conference took different approaches to the protection of photographic works. However, as a number of the

\footnotetext{
29 "WIPO-Administered Treaties, Contracting Parties of the Berne Convention" World Intellectual Property Organization <http://www.wipo.int/>.

${ }^{30}$ Records of the Berlin Conference of 1908, above n 9: "It should be noted at the outset that this last paragraph is totally unnecessary. A copyright work of art, such as a painting or a statue, cannot be reproduced by means of photography, any more so than by any other means, without the author's permission. If a sculptor has given a photographer the exclusive right to reproduce his statue, the photographer may take legal action against unauthorized photographs; he exercises a derived right, irrespective of the right he may have in his own name." (Emphasis added) This means that the rights owned by the photographer over photographs of that statue depend on the sculptor's rights over the statue. In other words, the photographer does not have exclusive rights over the photographs.
} 
parties at the conference refused to grant protection to them as artistic works, the discussion about whether they should be protected came to an end, with no unanimous agreement obtained. ${ }^{31}$ Some of the countries represented at the Berne Conference did not consider photographs or any photographic works as artistic works in their domestic laws. ${ }^{32}$ In the debate, the argument was brought up that the producing a photograph did not require skill. To produce a photograph only required the simple operation of pushing a button, which that did not require creativity. ${ }^{33}$ Despite the various skills involved in photography, such as the arrangement of subject, lighting, and perspective, some countries considered photographic works to be less valuable. ${ }^{34}$ However, to satisfy the demand for protection from the countries whose copyright laws protected photographic works as artistic works, the provision related to photographic works was included in the Final Protocol of the Berne Convention (1886): ${ }^{35}$

As regards Article 4 it is agreed that those countries of the Union where the character of artistic works is not refused to photographs engage to admit them to the benefits of the Convention concluded today, from the date of its coming into force. They shall, however, not be bound to protect the authors of such works further than is permitted by their own legislation except in the case of international engagements already existing, or which may hereafter be entered into by them.

It is understood that an authorized photograph of a protected work of art shall enjoy legal protection in all the countries of the Union, as contemplated by the said Convention, for the same period as the principal right of reproduction of the work itself subsists, and within the limits of private agreements between those who have legal rights.

This provision made a distinction between "artistic photographs" and "photographs of copyright-protected works" 36 , both of which were protected under the Berne Convention (1886), and "other photographs" 37 such as photographs of views, landscapes, buildings, portraits, and artistic works in the public domain. Photographs were protected under the Berne Convention (1886) as long as they were considered to be artistic works in the domestic law of the countries of the Union. One of the

\footnotetext{
${ }^{31}$ Ricketson and Ginsburg, above n 8, at 442 .

${ }^{32}$ Ladas, above $\mathrm{n} 8$, at 227.

${ }^{33}$ Silke von Lewinski International Copyright Law and Policy (Oxford University Press Inc., New York, 2008) at 176.

${ }^{34}$ Ricketson and Ginsburg, above n 8, at 443.

${ }^{35}$ Berne Convention, Final Protocol no 1.

${ }^{36}$ Ladas, above $\mathrm{n} 8$, at 227.

${ }^{37}$ At 227."Other photographs" refer to any photographs other than photographs of copyright-protected works.
} 
downsides of the provision was that the protection of "other photographs" could not be claimed under the Berne Convention (1886). ${ }^{38}$

Additional Act Amending Articles 2, 3, 5, 7, 12, and 20, of the Convention of September 9, 1886

At the Paris Conference of 1896, it was agreed that the protection afforded to photographs should be expanded. ${ }^{39}$ Not all of the countries of the Union ratified the Paris Additional Act $(1896)^{40}$, but the Act provided protection without depending on the recognition of photographs as artistic works ${ }^{41}$ in its contracting states' jurisdictions as stipulated in Art 2 of this Act: ${ }^{42}$

Photographic works and works produced by an analogous process shall be admitted to the benefits of these engagements in so far as the domestic laws of each State may permit, and to the extent of the protection accorded by such laws to similar national works.

This provision was a step towards a compulsory copyright protection for photographic works in the countries of the Union. ${ }^{43}$ However, Berlin Conference in 1908 found that this provision was made without reciprocity between countries of the Union. ${ }^{44}$

\footnotetext{
${ }^{38}$ At 228. "Other photographs" were protected only in the countries of the Union which domestic laws provided that the photographs were considered as artistic works.

${ }^{39}$ At 229. See Additional Act Amending Articles 2, 3, 5, 7, 12, and 20, of the Convention of September 9, 1886, and Numbers 1 and 4 of the Final Protocol Annexed Thereto (completed 4 May 1896) [Paris Additional Act], art 2.

${ }^{40}$ Ladas, above n 8, at 230. Norway and Sweden did not ratify the Paris Additional Act. Therefore, the other countries of the Union could not claim the protection for photographs under the Paris Additional Act in these countries.

${ }^{41}$ At 230.

${ }^{42}$ Paris Additional Act, art 2.

43 "Records of the Diplomatic Conference: Convened in Paris, April 15 to May 4, 1896" in Sam Ricketson and Jane C Ginsburg International Copyright and Neighbouring Rights: The Berne Convention and Beyond <http://global.oup.com> (Records of the Paris Conference of 1896). The parties of the Conference admitted "as to photographs, which had already been left out of Article 4 in 1885 , agreement still could not be reached on introducing them, as several laws refuse to recognize them as having the character of artistic works, while nevertheless affording them special protection." However, it was then agreed to enlarge the protection to not only based on having the character of artistic works: "...in those countries which do not grant photographic works the character of works of art, photographs will be protected pursuant to the provisions of those countries' legislation, without those who claim this protection having to meet other conditions and formalities than those laid down by the laws of the country of origin."

${ }^{44}$ Records of the Berlin Conference of 1908, above n 9. "The consequence of the clause adopted in 1896 was that those countries of the Union where the legislator did not grant photographs any protection were not obliged to protect the photographs of the other Union countries, and yet benefited from the protection granted by the latter countries. A concession was thus made here without reciprocity."
} 


\section{Revised Berne Convention for the Protection of Literary and Artistic Works of 1908}

Photographic works finally obtained copyright protection similar ${ }^{45}$ to that afforded to other literary and artistic works protected by the Berne Convention for the first time, under the Berlin Act (1908), although photographic works were not yet considered as artistic works. Art 3 of the Act stated: ${ }^{46}$

The present Convention shall apply to photographic works and to works produced by a process analogous to photography. The contracting countries shall be bound to make provision for their protection.

This provision was derived from Final Protocol No. 1 of the Berne Convention and art 2 of the Paris Additional Act (1896), and the scope of protection was widened to photographic works and works obtained by any process analogous to photography. ${ }^{47}$

Although a provision in the Berne Convention (1886) stated that the copyright of authorised photographs was protected, that provision was eventually dropped from the amendment of the Paris Additional Act (1896) by the Berlin Act (1908). The second paragraph of the Paris Additional Act (1896) that protected "authorised photographs of copyright-protected works" 48 was deleted at the Berlin Conference, with the following consideration: ${ }^{49}$

It should be noted at the outset that this last paragraph is totally unnecessary. A copyright work of art, such as a painting or a statue, cannot be reproduced by means of photography, any more so than by any other means, without the author's permission. If a sculptor has given a photographer the exclusive right to reproduce his statue, the photographer may take legal action against unauthorized photographs; he exercises a derived right, irrespective of the right he may have in his own name.

\footnotetext{
${ }^{45}$ Copyright for photographic works was protected in the Berlin Act 1908, but photographic works were not yet considered as a form of artistic works. The debate on recognition for photographic works as artistic works was mentioned in Records of the Berlin Conference of 1908, above n 9: "In certain countries, photographic works do not enjoy specific protection but are assimilated to artistic works and consequently benefit from the protection afforded to them. Such countries naturally asked for photographs to be included in the list of works to which the Convention applied. This was refused by the countries which did not protect photographs or only protected them on a specific basis, not as artistic works."

${ }^{46}$ Revised Berne Convention for the Protection of Literary and Artistic Works (opened for signature 9 September 1886, completed 20 March 1914) [Berlin Act 1908], art 3.

47 "Photographic works include the negative proof, the cliché, as well as the positive proof, the ordinary photograph. Processes similar to photography are, for instance, pyrography, heliography and photographic impression on stones, metals and glass." Ladas, above n 8, at 232.

${ }^{48}$ Berne Convention, Final Protocol no 1.

${ }^{49}$ Records of the Berlin Conference of 1908, above n 9 (emphasis added).
} 
Although the countries of the Union made an agreement to protect the copyright of photographic works after the amendment of the Berlin Act (1908), different terms of copyright protection for photographic works were made throughout the years of Berne Convention amendments. The minimum term of protection for literary and artistic works was first introduced in art 7 of the Berlin Act (1908), which provided protection for "the life of the author and fifty years after his death". ${ }^{50}$ However, different provision applied to the term of copyright protection for photographic works in the Berlin Act (1908), stated as follows: ${ }^{51}$

For photographic works and works produced by a process analogous to photography, for posthumous works, for anonymous or pseudonymous works, the term of protection shall be regulated by the law of the country where protection is claimed, provided that the said term shall not exceed the term fixed in the country of origin of the work.

The Berlin Act (1908) did not determine a minimum term of protection for photographic works as it had for other literary and artistic works in art 7. A number of delegations at the Berlin Conference of 1908 were willing to establish that photographs would be protected for at least 15 years from the date of publication. However, objections were made in relation to either the term or the starting point and a standardised term for the international protection of photographs. The committee to the Berlin Conference then reported that it had not been possible to agree on a "uniform term". 52

$4 \quad$ International Convention for the Protection of Literary and Artistic Works of 1928

The provision regarding copyright protection for photographic works in the Berlin Act (1908) remained in the Rome Act (1928). The records of the Rome Conference stated that "it was unanimously agreed that they should be dealt with in Article 3, as hitherto, and not in Article 2". 53

\footnotetext{
${ }^{50}$ Berlin Act 1908, art 7 para 1 . The same term of protection provided in Paris Act 1971, art 7(1).

${ }^{51}$ Article 7 para 2.

${ }^{52}$ Records of the Berlin Conference of 1908, above $n 9$.

${ }^{53}$ International Convention for the Protection of Literary and Artistic Works (opened for signature 9 September 1886, last amended 2 June 1928) [Rome Act 1928], art 3. See also "Records of the Diplomatic Conference: Convened in Rome, May 7 to June 2, 1928" in Sam Ricketson and Jane C Ginsburg International Copyright and Neighbouring Rights: The Berne Convention and Beyond (9 December 2005) Oxford University Press <http://global.oup.com> (Records of the Rome Conference of 1928).
} 
It was agreed in the Berlin Act (1908) that the countries of the Union to be able to freely determine the term of protection in their domestic law. The same provision remained in art 7(3) of the Rome Act (1928) after a similar debate. ${ }^{54}$ Because the provision that was incorporated in art 3 of the Berlin Act (1908) was not to be regarded as an obligation for a country to provide for such formalities in its domestic law, the majority of the countries of the Union in the Rome Conference of 1928 opposed the measure to standardise the term of protection for photographic works. ${ }^{55}$

\section{Berne Convention for the Protection of Literary and Artistic Works of 1948}

In the Brussels Act (1948), photographic works were finally recognised as artistic works protected by the Convention, ${ }^{56}$ and the same provision remains in the current version of the Convention. The types of works that are protected by copyright are mentioned in the second article of the Brussels Act (1948): ${ }^{57}$

The term 'literary and artistic works' shall include every production in the literary, scientific and artistic domain, whatever may be the mode or form of its expression, such as books, pamphlets and other writings; ... works of drawing, painting, architecture, sculpture, engraving and lithography; photographic works and works produced by a process analogous to photography; ...

The provision regarding the term of protection in art 7(3) of the Brussels Act (1948) was enacted based on the proposal to maintain art 7(3) of the Rome Act (1928) "in so far as it concerns photographic works or those obtained by a process analogous to photography". 58

\footnotetext{
${ }^{54}$ The reporting chairman of sub-committee for cinematography and photography in this Conference, Georg Klauer, reported that there had been a debate that France and Switzerland had proposed for the amendment to set a minimum term of protection for photographs of twenty years following the publication of the photographs. On the other hand, Japan declared that it could not endorse anything other than a ten-year term. Records of the Rome Conference of 1928, above n 53.

${ }^{55}$ Records of the Rome Conference of 1928, above $\mathrm{n} 53$.

${ }^{56}$ Brussels Act 1948, art 2(1). "Records of the Diplomatic Conference: Convened in Brussels, June 5 to 26, 1948" in Sam Ricketson and Jane C Ginsburg International Copyright and Neighbouring Rights: The Berne Convention and Beyond (9 December 2005) Oxford University Press <http://global.oup.com> (Records of the Brussels Conference of 1948) also commenting on the originality of the copyright-protected photographs as follows: "The Sub-Committee discussed whether it should be specified in the text that only photographic works having the character of personal creations were protected. There was doubt as to the appropriateness of such a step, and no agreement could be reached. It was not that the idea thus expressed was incorrect, but it seemed that a criterion which applied to all the productions governed by the Convention should not be mentioned in connection with a particular category of works such as photographic works" (emphasis added).

${ }^{57}$ Paris Act 1971, art 2(1) (emphasis added).

${ }^{58}$ It was stated in the records that the sub-committee on photography and cinematography realised the impossibility of achieving agreement on a uniform term. Records of the Brussels Conference of 1948, above n 56.
} 
The Berne Convention for the Protection of Literary and Artistic Works of 1967, or the Stockholm Act (1967), did not change the protection for photographic works as provided for in the text of the Brussels Act (1948). However, the wording in art 2 of the Brussels Act (1948) was changed. The sentence in art 2 of the Stockholm Act (1967), although it did not change the protection afforded to photographic works, is as follows: ${ }^{59}$

The expression 'literary and artistic works' shall include ... photographic works to which are assimilated works expressed by a process analogous to photography; works of applied art; illustrations, maps, plans, sketches and three-dimensional works relative to geography, topography, architecture or science.

The minimum term of protection for photographic works, discussion about which was not concluded during the discussion of the Rome Act (1928) and was not even brought up in discussions about the Brussels Act (1948), was finally determined in art 7(4) of the Stockholm Act (1967). It determined that copyright "shall last at least until the end of a period of twenty-five years from the making of such a work". ${ }^{60}$ This provision was made based on arguments during the Intellectual Property Conference of Stockholm of 1967 that "countries should not be completely free to determine protection" and "they should observe the minimum term of protection". ${ }^{61}$

The term of protection under art 7(4) of the Stockholm Act (1967) is currently provided under art 7(4) of the Paris Act (1971), which provides for a minimum term of protection for photographic works of twenty-five years, starting from the making of the works. ${ }^{62}$

7 Berne Convention for the Protection of Literary and Artistic Works of 1971 and WIPO Copyright Treaty of 1996

\footnotetext{
${ }^{59}$ Article 2(1). This provision was adopted from Stockholm Act 1967, art 2(1) (emphasis added).

${ }^{60}$ Berne Convention for the Protection of Literary and Artistic Works (opened for signature 9 September 1886, last amended 14 July 1967) [Stockholm Act 1967], art 7(4).

61 "Records of the Intellectual Property Conference of Stockholm: June 11 to July 14, 1967 Volume II" in Sam Ricketson and Jane C Ginsburg International Copyright and Neighbouring Rights: The Berne Convention and Beyond (9 December 2005) Oxford University Press <http://global.oup.com> (Records of the Intellectual Property Conference of Stockholm of 1967). Portugal proposed that a period of ten years should be substituted for the period of twenty-five years proposed. The United Kingdom proposed that the term of protection should last for at least fifty years from the making of the photograph. The committee of Stockholm Conference of 1967 then decided to adopt the text proposed in the Programme, which is the period of twenty-five years from the making of the works.

${ }^{62}$ Paris Act 1971, art 7(4).
} 
The provision related to copyright protection for photographic works in the Stockholm Act (1967) was adopted as it was at the Paris Conference of 1971 and it is now binding over 166 countries under the Paris Act (1971). There is no further explanation as to why the minimum term of protection for photographic works is different from the other. ${ }^{63}$ The reason behind this provision for photographic works could be the nature of photographic works. When photographic works were first protected, the protection only covered photographic works that were considered to be "artistic works". To protect all photographic works without having to differentiate their artistic aspects but also to recognise that they were previously not entirely considered artistic works, it was considered wise to provide a different kind of protection for them, which lead to a term of protection different to those afforded to other artistic works. Another reason might have been because the members of the countries of the Union had different provisions or criteria by which they determined the originality of photographic works.

However, different terms of protection for photographs are applicable for the contracting states of the WIPO Copyright Treaty, which is the same as the general term of "life plus fifty" 64 . This provision is stated in art 9 of the Treaty as "in respect of photographic works, the Contracting Parties shall not apply the provisions of Article 7(4) of the Berne Convention". ${ }^{65}$ This means that there is an international effort to give the same term of protection, for photographic works.

\section{$8 \quad$ Copyright Protection for Photographs of Copyright-Protected Works}

The discussion related to the provision regarding copyright protection for photographs of copyright-protected works was not mentioned in any further amendments to the Berne Convention after the Berlin Act (1908). ${ }^{66}$ However, the Brussels Conference of 1948 produced a provision that allowed the press to photograph literary and artistic works for the purpose of reporting events: ${ }^{67}$

\footnotetext{
${ }^{63}$ Work of applied arts also has the same minimum term of protection as photographic works, which is 25 years from the making of the works, and there is no further explanation for this provision.

${ }^{64}$ Justin Hughes “The Photographer's Copyright - Photograph as Art, Photograph as Database” (2012) 25 Harv J L \& Tech 327 at 330. See WIPO Chapter 5 International Treaties and Conventions on Intellectual Property <http://www.wipo.int/> at 5.242. There are 90 states that have become a party to this Treaty as of 15 April 2013, including United States of America and Indonesia. On the other hand, New Zealand has not become a party.

${ }^{65}$ World Intellectual Property Organization Copyright Treaty (opened for signature 20 December 1996, entry into force 6 March 2002) [WIPO Copyright Treaty], art 9.

${ }^{66}$ Berne Convention, Final Provision No. 1. The same provision remained in Paris Additional Act, art 2.

${ }^{67}$ Brussels Act 1948, art 10bis.
} 
It shall be a matter for legislation in countries of the Union to determine the conditions under which recording, reproduction, and public communication of short extracts from literary and artistic works may be made for the purpose of reporting current events by means of photography or cinematography or by radiodiffusion [sic].

One of the purposes of art 10bis of the Brussels Act (1948) is to extend the right to borrow and for the purpose of short quotations in the case of reporting current events by means of photography. ${ }^{68}$ Article 10bis (2) of the Stockholm Act (1967), later on adopted as art 10bis (2) of the Paris Act (1971), contained the same provision. However, the Paris Act (1971) does not stipulate any provisions related to exceptions or prohibitions in the taking photographs of copyright-protected works for personal or commercial purposes other than reporting events by the press, although it was once mentioned in Final Protocol no 1 of the Berne Convention (1886).

Besides allowing for reporting events by the press, the Convention also authorizes the members of the Union to allow "fair practice" of copyright-protected works. This provision, stated in art 10 of the Paris Act (1971), states that "it shall be permissible to make quotations from a work which has already been lawfully made available to the public, provided that their making is compatible with fair practice". 99 Although the Paris Act (1971) only provided that a reference to the author should be made in the use of a copyright-protected work under "fair practice" "70, copyright law in the United States and Indonesia recognised that "fair practice" does not include the use of the work for commercial purposes. ${ }^{71}$

Taking photographs of copyright-protected works could be considered as reproducing ${ }^{72}$ or making adaptations or derivative works of the copyright-protected works. The results of reproducing and making adaptations or derivative works of copyright-protected works are also protected by copyright, as they are mentioned in the Paris Act (1971). Although the term of protection for photographic works differs from some other copyright-protected works under the Paris Act (1971), it can be concluded that photographs of copyright-protected works are protected by copyright provided that the photographs are authorised by the authors of the copyright-protected works, provided that the photographs attain the appropriate originality level. ${ }^{73}$

\footnotetext{
${ }^{68}$ Records of the Brussels Conference of 1948, above $\mathrm{n} 56$.

${ }^{69}$ Paris Act 1971, art 10(1).

${ }^{70}$ Article 10(3).

${ }^{71}$ Copyright Act 17 USC $\S \S 107$ and Indonesian Copyright Law 2002, art 15.

${ }^{72}$ Records of the Berlin Conference of 1908, above $n 9$.

${ }^{73}$ Paris Act 1971, art 9(1) and 12.
} 


\section{B History of Copyright Protection for Architectural and Sculptural Works}

In order to identify the basis of the copyright protection for photographs of architectural and sculptural works, the discussion should begin with the nature of copyright protection afforded to architectural and sculptural works. Copyright for architectural and sculptural works is also protected in art 2 of the Paris Act (1971). For the purpose of the protection, the Convention stated that the country of origin of architectural and sculptural works is not the country of nationality of the authors but the country in which the works are erected. ${ }^{74}$ The same provision also applies to other artistic works incorporated in a building or other structure, including sculptures, located in one of the member states of the Convention. However, the Convention only provides for basic copyright protection. The member states are allowed to give further protection in their domestic law. Therefore, it is necessary to refer to the domestic legislation of a country to determine whether further copyright protection for architectural and sculptural works exists.

\section{$1 \quad$ Architectural Works}

Copyright for architectural works has been protected since the Berne Convention (1886) came into force. However, it was mentioned that the protection was given to solely architectural works and works that are related to the making of architectural works such as the sketches and models were not protected as a part of "architectural works" ${ }^{\text {"75 }}$. This provision was afterwards discussed in Paris Conference of 1896, which resulted in the following amendment to the Paris Additional Act (1896): ${ }^{76}$

In countries of the Union where protection is accorded not only to architectural plans, but also to the architectural works themselves, these works shall be admitted to the benefits of the Berne Convention and of the present Additional Act.

In Berlin Act (1908), the protection afforded to architectural works and plans that was previously only provided in some countries of the Union, became compulsory to be protected in all countries of the Union. Art 2 of the Berlin Convention (1908) stated as follows: ${ }^{77}$

The expression 'literary and artistic works' shall include any production in the literary, scientific or artistic domain, whatever may be the mode or form of its

\footnotetext{
${ }^{74}$ Article 5(4)(c)(ii).

${ }^{75}$ Sketches and models are protected as artistic works, but not under "works of architecture" in Berne Convention 1886.

${ }^{76}$ Paris Additional Act 1896, art 2.

${ }^{77}$ Berlin Convention 1908, art 2.
} 
reproduction, such as ... works of drawing, painting, architecture, sculpture, engraving and lithography; ... plans, sketches, and plastic works relative to geography, topography, architecture ...

This provision remains in the other amendments of the Berne Convention (1886) and is currently applicable through art 2 of the Paris Act (1971). However, it was actually stated that "the construction of a work of architecture shall not constitute a publication" ${ }^{, 78}$ and that, therefore, copyright protection for architectural works would begin after construction was complete, with the protection granted for the life of the author and fifty years after his death. ${ }^{79}$ This could mean that architectural works are only protected under copyright law as a whole when the works have been built, with parts of architectural works already completed during the construction process not protected until then.

When the term of protection for architectural works begins was discussed and has been clearly implemented. ${ }^{80}$ However, there is no limitation on or exception to the protection stated in the Paris Act (1971) — for example, regarding permission for others to take photographs of parts of architectural works that are permanently situated in public places. There is also no specific definition regarding the making copies of architectural works, whether it is a building with similar characteristics to the "copied" building, or whether it also includes photographs of a building. Therefore, taking photographs of copyright-protected architectural works under the freedom of panorama is not stated to be prohibited but also not stated as being allowed under the Paris Act (1971).

\section{$2 \quad$ Sculptural Works}

Copyright protection for sculptural works has always been protected in the Berne Convention (1886) and its amendments. The protection has never been debated or changed and it remains in art 2 of the Paris Act (1971). Although it was not explicitly stated, plans and sketches of sculptural works are protected as drawings. ${ }^{81}$ The term of protection for sculptural works is also the same as architectural works, which is for the life of the author and fifty years after his death. ${ }^{82}$

\footnotetext{
${ }^{78}$ Paris Act 1971, art 3(3).

${ }^{79}$ Article 7(1).

${ }^{80}$ Article 3(3). The protection starts from the date of publication and "the construction of a work of architecture shall not constitute publication".

${ }^{81}$ Article 2(1).

${ }^{82}$ Article 7(1).
} 
Similar to the protection for architectural works, there is also no specific definition regarding making copies of sculptural works permanently situated in public places related to taking photographs of a sculpture under the freedom of panorama. Therefore, similar to the case between taking photographs of architectural works and the freedom of panorama, taking photographs of copyright-protected sculptural works under the freedom of panorama is not prohibited but also not being mentioned as allowed under the Paris Act (1971).

\section{Jurisdictional Comparison of Copyright Laws}

\section{A Overview of the Freedom of Panorama Provisions Internationally}

The freedom of panorama gives the right to photographers to take photographs of copyright-protected works that are permanently situated in public places without having to gain the consent of the authors of those works. The copyright laws of several countries, such as the United States and New Zealand, have provisions for this freedom, although they are not precisely regulated the same way. The freedom of panorama is also available in other countries such as Australia ${ }^{83}$, Malaysia ${ }^{84}$, and Singapore $^{85}$. However, there are countries where freedom of panorama is not recognised in their copyright laws, such as in Italy where the copyright-protected photographic works does not include photographs of copyright-protected works. Copyright for photographic works in Italy is only given to "images of persons or of aspects, elements or events of natural or social life" 86 and, therefore, copyright law in Italy does not protect photographs that are taken under the freedom of panorama.

Besides the countries in which copyright laws clearly protect or do not protect the freedom of panorama, there are also some countries that do not have specific provisions related to the freedom of panorama. An example is Indonesia. ${ }^{87}$ Its copyright law does not mention or list what kinds of photographs are protected, which creates ambiguity as to whether it should include the photographs of copyrightprotected works. Although photographic works are protected under the Indonesian Copyright Law 2002 in a similar way to how they are protected under the copyright laws of the United States and New Zealand, freedom of panorama is not mentioned in the legislation

\footnotetext{
${ }^{83}$ Copyright Act 1968 (Cth), s 65.

${ }^{84}$ Akta Hakcipta [Copyright Act] 1987 (Malaysia), s 13(2)(d).

${ }^{85}$ Copyright Act 1988 (Singapore), s 63.

${ }^{86}$ Protezione del dirittod'autore e di altridiritticonnessi al suoesercizio [Law for the Protection of Copyright and Neighbouring Rights] 1941 (Italy), art 87. English translation by World Intellectual Property Organization <http://www.wipo.int>.

${ }^{87}$ Indonesian Copyright Law 2002, art 14.
} 
This chapter discusses the comparison between copyright laws in the United States, New Zealand, and Indonesia. The first reason behind the selection of these countries is that the copyright laws in these countries give exclusive rights, including moral rights and economic rights, to the copyright owner of photographic works, as mandated under the Berne Convention. However, there is a difference. The United States and New Zealand protect the freedom of panorama in their copyright law while the Indonesian Copyright Law 2002 does not mention anything about the freedom of panorama. The freedom of panorama discussed in this part only focuses on its effect on photographic works, and not to other artistic works containing copyright-protected works. This is because the copyright law in the United States only protects the freedom of panorama for pictorial representations of architectural works, ${ }^{88}$ while the New Zealand Copyright Act 1994 provides a wider protection for the freedom of panorama which is not limited to photographic works but also in relation to architectural works. ${ }^{89}$ To make a fair comparison between these countries, this paper limits its discussion to the freedom of panorama and photographic works.

Although the copyright laws of both the United States and New Zealand protect the freedom of panorama, it also appears that the laws provide a different kind of protection and provide certain limitations on that freedom. After looking at the differences and considerations that give protection to and provide limitations on the freedom of panorama in the United States and New Zealand, this chapter examines whether the freedom of panorama is actually protected under the Indonesian Copyright Law 2002 despite it not being explicitly mentioned. What was called the "Paris Act (1971)" in the previous part is hitherto referred to it as "the Berne Convention".

It is then the questions to determine whether the photographs taken under the freedom of panorama are protected as copyrightable artistic works and whether the photographers who take photographs under the freedom of panorama are eligible as the copyright owner of the photographs in the United States, New Zealand, and Indonesia. If the photographs are protected, then the authors of the photographs would be able to exercise those rights that are previously mentioned. Then the acknowledged authors of the photographs should be determined, is it the photographer who took the photographs of the works, or the architect or the sculptor who made the works?

\footnotetext{
${ }^{88}$ Copyright Act 17 USC $\$ 120(a)$.

${ }^{89}$ Copyright Act 1994, s 73. It provides protection for graphic work, photograph or film, and visual image of buildings, sculptures, models for buildings, or works of artistic craftsmanship that are permanently situated in a public place.
} 
Assuming that photographs which are taken under the freedom of panorama are protected by art 2 of the Berne Convention, and therefore the protection should be given within the jurisdiction of the countries of the Union, the photographers or the copyright owner of photographs should be able to exercise their moral rights and economic rights of the photographs without the permission from the copyright owners of architectural and sculptural works. This condition should not be seen as limiting the economic rights of architects and sculptors over the copyright-protected architectural and sculptural works, because the photographs are considered as original artistic works and have a separate copyright protection.

\section{B $\quad$ United States}

\section{$1 \quad$ Exclusive Rights}

The exclusive rights from copyright protection are obtained by the copyright owner, which usually are the authors of the copyright-protected works. Although the Berne Convention mandates some rights which fall under the exclusive rights ${ }^{90}$, the acts that are included under the exclusive rights can vary in accordance with copyright laws in several countries.

In the United States copyright legislation (Title 17 USC), the copyright owner has the exclusive rights to do or to authorise other people to do any of the following acts: ${ }^{11}$

(1) to reproduce the copyrighted work in copies or phonorecords [sic];

(2) to prepare derivative works based upon the copyrighted work;

(3) to distribute copies or phonorecords of the copyrighted work to the public by sale or other transfer of ownership, or by rental, lease, or lending;

(4) in the case of literary, musical, dramatic, and choreographic works, pantomimes, and motion pictures and other audiovisual works, to perform the copyrighted work publicly;

(5) in the case of literary, musical, dramatic, and choreographic works, pantomimes, and pictorial, graphic, or sculptural works, including the individual images of a motion picture or other audiovisual work, to display the copyrighted work publicly; and

(6) in the case of sound recordings, to perform the copyrighted work publicly by means of a digital audio transmission.

\footnotetext{
${ }^{90}$ For example, art 8 of the Berne Convention provides that the authors shall have the exclusive rights to authorise the making of translation of their works and art 9(1) of the Berne Convention provides that that the authors shall have the exclusive rights to authorise reproduction of their works.

${ }^{91}$ Copyright Act 17 USC $§ 106$.
} 
Although Title 17 USC $\S 106$ has set out the exclusive rights held by the copyright owners, it appears that the Law provides another scope of exclusive rights in architectural works in Title 17 USC $\S 120$. This part of the copyright law in the United States was added in 1990 by the Architectural Works Copyright Protection Act, which deemed applicable to any work created on or after the date it was enacted, which was on 1 December $1990 .^{92}$ This provision also relates to what Newell coined as the "freedom of panorama", which will be discussed on the next part below.

Based on Title 17 USC, copyright protection, in general, is given to the following works: $:^{93}$

$\ldots$ original $^{94}$ works of authorship fixed in any tangible medium of expression, now known or later developed, from which they can be perceived, reproduced, or otherwise communicated, either directly or with the aid of a machine or device. ...

Copyright protection also subsists for compilations and derivative works. However, the copyright for compilations and derivative works is different from the original works and its copyright "does not affect or enlarge the scope, duration, ownership, or subsistence of, any copyright protection in the pre-existing material" 95 .

\section{$2 \quad$ Freedom of Panorama}

The copyright law in the United States provides the protection to take photographs of architectural works which is one of the parts of the term "freedom of panorama". Long before the provision in Title 17 USC $\S 120$ (a) that protects the freedom of panorama was enacted, a judgment on Pagano $v$ Chas Beseler $\mathrm{Co}^{96}$ regarding copyright protection for a photograph of a public place that displayed the Public Library building on it had come into a decision that involved an argument on photographs of architectural works that are permanently situated in public places should gain copyright protection as "derivative works" 97 of the works. This case

\footnotetext{
${ }^{92}$ United States Copyright Office "Copyright Law of the United States of America and Related Laws Contained in Title 17 of the United States Code" <http://www.copyright.gov/>.

${ }^{93}$ Copyright Act 17 USC $\S 102(a)$.

${ }^{94}$ United States Copyright Office, above n 92. This requirement has two facets: the author must have engaged in some intellectual endeavour of her own, and not just have copied from a pre-existing source, and, in addition to being the author's independent creation, the work must exhibit a minimal amount of creativity. (at 116) The phrase "original works of authorship", which is purposively left undefined, is intended to incorporate without change the standard of originality established by the courts under the present copyright statute. (at 377)

${ }^{95}$ Copyright Act 17 USC \& 103(b).

${ }^{96}$ Pagano, et al $v$ Chas Beseler Co 234 F 963 (SD NY 1916).

${ }^{97}$ Copyright Act 17 USC $§ 103$ (b) provides that "copyright in a compilation or derivative work extends only to the material contributed by the author of such work, as distinguished from the preexisting [sic] material ..."
} 
started when Pagano sued the Company for copyright infringement of his photograph, which was taken in front of the New York Public Library. The Court held that "the photograph, with its particular lighting and people in various stances, was the proper subject of a copyright" 98 and therefore it was out of the question if a photograph of a public building could be copyrighted or not, regardless of the current copyright protection for the depicted building. This means that Pagano's photograph should gain copyright protection and exact reproduction of the photograph should be seen as infringement to copyright. ${ }^{99}$

Following Pagano, photographs of architectural works are protected in the United States; in other words, a provision in line with the freedom of panorama exists in law, albeit at this point only in the law of the United States. Today, legislation in the United States, Title 17 USC, describes the protection of the freedom of panorama as follows: ${ }^{100}$

The copyright in an architectural work ${ }^{\mathbf{1 0 1}}$ that has been constructed does not include the right to prevent the making, distributing, or public display of pictures, paintings, photographs, or other pictorial representations of the work, if the building in which the work is embodied is located in or ordinarily visible from a public place.

This provision does not fall under the limitations on exclusive rights, which are available in sections 107-112 of the Law, and therefore the right to take photographs of architectural works is not considered to be part of the exclusive rights. It also means that the right to take photographs of architectural works is not exclusively held by the architects. Under the provision they would not be able to prevent others from taking photographs of their copyright-protected works that are permanently situated in, or visible from, public places.

Although Title 17 USC $\S 120$ (a) seem to provide flawless protection for photographs of copyright-protected architectural works, some points remain to be looked at in regards to the freedom of panorama. Firstly, the protection does not mention the right to photograph sculptural works that are permanently situated in public places. Therefore, although the provision in Title 17 USC $\S 120$ (a) accommodates the freedom of panorama, it does not necessarily protect the right to photograph all copyright-protected works that are permanently situated in or visible from public places. By only looking at the legislation, it is not clear whether taking photographs of

\footnotetext{
${ }^{98}$ Pagano, et al v Chas Beseler Co 234 F 963 (SD NY 1916) at 963.

${ }^{99}$ At 964.

${ }^{100}$ Copyright Act 17 USC $\S 120$ (a) (emphasis added).

${ }^{101}$ Copyright Act 17 USC $\S 101$ defined architectural work as "the design of a building as embodied in any tangible medium of expression, including a building, architectural plans, or drawings".
} 
sculptural works which are permanently situated in public places is allowed in the same sense that taking photographs of architectural works if the works are permanently situated in or visible from public places.

Secondly, the protection does not mention the right to gain commercial advantage from the making, distributing, or displaying of photographs of architectural works. Therefore, the copyright owner of photographs of architectural works in the United States can only gain commercial advantage from the photographs taken under the freedom of panorama if the photographs are considered to be new artistic works. Under the circumstances where such photographs are considered to be artistic works, the copyright owner would be granted with exclusive rights and therefore able to gain commercial advantage from them.

\section{$3 \quad$ Moral Rights in the Freedom of Panorama}

Aside from exclusive rights, the authors of copyright-protected works also obtain moral rights attached to the works. The protection of moral rights varies between jurisdictions. Based on the Title 17 USC, moral rights are only granted to a limited category of authors: ${ }^{102}$

Only the author of $a$ work of visual art has the rights conferred by subsection (a) in that work, whether or not the author is the copyright owner. The authors of a joint work of visual art are coowners [sic] of the rights conferred by subsection (a) in that work.

As Title 17 USC limits the protection for moral rights to the authors of "a work of visual art", it is important to know which copyright-protected works in the United States falls under that term to determine whether photographic, architectural, and sculptural works are recognised as works of visual art. Title 17 USC $\S 101$ define the phrase as follows: ${ }^{103}$

A "work of visual art" is-

(1) a painting, drawing, print or sculpture, existing in a single copy, in a limited edition of 200 copies or fewer that are signed and consecutively numbered by the author, or, in the case of a sculpture, in multiple cast, carved, or fabricated sculptures of 200 or fewer that are consecutively numbered by the author and bear the signature or other identifying mark of the author; or

\footnotetext{
${ }^{102}$ Copyright Act 17 USC $\$ 106 \mathrm{~A}(\mathrm{~b})$ (emphasis added).

$103 \S 101$.
} 
(2) a still photographic image produced for exhibition purposes only, existing in a single copy that is signed by the author, or in a limited edition of 200 copies or fewer that are signed and consecutively numbered by the author.

A work of visual art does not include-

(A)(i) any poster, map, globe, chart, technical drawing, diagram, model, applied art, motion picture or other audiovisual [sic] work, book, magazine, newspaper, periodical, data base, electronic information service, electronic publication, or similar publication;

(ii) any merchandising item or advertising, promotional, descriptive, covering, or packaging material or container;

(iii) any portion or part of any item described in clause (i) or (ii);

(B) any work made for hire; or

(C) any work not subject to copyright protection under this title.

On the one hand, by linking the definition of a work of visual art in Title17 USC $\S$ $101 \mathrm{a}$ and to the definition of moral rights in Title 17 USC $\S 106 \mathrm{~A}$, the provision in Title 17 USC $\S 106 \mathrm{~A}$ means that the moral rights of architects are not protected in the United States, although architects would still be entitled to gain copyright protection under Title 17 USC $\S 201$. On the other hand, the protection for moral rights is limited to certain number of copies of the protected works, including for sculptural works. Photographic works are treated differently. Title 17 USC $\S 106$ A only protects the moral rights of the authors of photographic works where the works are produced for exhibition purposes only, and the protection only applies to specified number of copies.

In relation to the freedom of panorama, a photograph of a building that was taken under the freedom of panorama in the United States should be protected as a new artistic work and should indicate its photographer as the author. Under Title 17 USC $\S$ 120(a) photographers are allowed to take photographs of architectural works without having gained the consent from the copyright owner, and the architects do not have their moral rights protected under Title 17 USC $\S 101$ and $\S 106 \mathrm{~A}$.

However, photographs of sculptural works are treated differently even when the works are permanently situated in, or visible from, public places. No provision allows an unauthorised person to take photographs of sculptural works, and therefore that act does not fall under the freedom of panorama in the United States. If an unauthorised person takes photographs of a sculptural work, then that person infringes the moral rights of the sculptor. 
Title 17 USC $§ 106 A$, which is also known as the Visual Artists Rights Act of 1990 or VARA, also provides provisions that are similar to what is known as "the right to object to derogatory treatment" 104 in the New Zealand Copyright Act 1994. Basically, this provision protects the authors from being identified as the authors of alteration of their works to which they did not agree, but that in any way would affect their reputation: ${ }^{105}$

[the author of a work of visual art] shall have the right to prevent the use of his or her name as the author of the work of visual art in the event of a distortion, mutilation, or other modification of the work which would be prejudicial to his or her honor [sic] or reputation.

An unauthorised person who takes photographs of sculptural works may be seen to be modifying the work of visual art without gaining prior consent from the author, and therefore infringing the author's right under Title 17 USC $\S 106 \mathrm{~A}(\mathrm{a})(3)(\mathrm{A})$. There is no exception for taking photographs of sculptural works, even in the case where the sculpture is permanently situated in a public place. It is not acceptable to use photographs of a sculptural work or works permanently situated in a public place without the permission from its copyright owner to gain commercial advantage for the reason of "fair use". 106

\section{$4 \quad$ Economic Rights in the Freedom of Panorama}

Title 17 USC does not state whether the copyright owner of photographs taken under the freedom of panorama is entitled to the exclusive right to gain commercial advantages from them. It also does not state whether photographs taken under the freedom of panorama constitute "original artistic works". However, there is case law that shows how Title 17 USC was implemented in relation to the photographs of copyright-protected works that are available in public places, and the ability of photographers to gain commercial advantages from them.

One of the cases related to the freedom of panorama is The Rock and Roll Hall of Fame and Museum, Inc, et al $v$ Gentile Productions, et al ${ }^{107}$. This case was actually focused on whether the publication and sale of a poster design that consisted of a photograph of the museum building taken by Charles $M$ Gentile was still under copyright protection. The photograph also carried the phrase "THE ROCK AND

\footnotetext{
${ }^{104}$ Copyright Act 1994, s 98.

${ }^{105}$ Copyright Act 17 USC $\$ 106 \mathrm{~A}(\mathrm{a})(3)(\mathrm{A})$.

${ }_{106}$ Gaylord v United States 595 F 3d 1364 (DC Cir 2010).

${ }^{107}$ The Rock and Roll Hall of Fame and Museum, Inc, et al v Gentile Productions, et al 71 F Supp 2d 755 (ND OH 1999).
} 
ROLL HALL OF FAME" which was registered and protected under trademark law when Gentile took and produced the photograph. ${ }^{108}$ However, this case was also related to the right to take photographs of architectural works which is protected under Title 17 USC $§ 120$ (a). It was pointed out by the representatives of the museum that, although taking photographs of the museum building was allowed under the law, Gentile should not be able to publish the photographs anywhere and should not be able to gain commercial advantage from them. However, the Court of Appeal reasoned: ${ }^{109}$

Furthermore, not only may Gentile take a photograph of the building, he can sell a photograph of it... Merely selling a poster of its own trademark does not give the Museum the right to enjoin every duplication [sic] of its mark, only those that compete directly with its own product in similar channels of commerce.

Opposing the arguments of The Rock and Roll Hall of Fame and Museum, it was stated in the judgment that the Court saw the photograph as "a photograph of a wellknown public landmark". ${ }^{110}$ Taking photographs of the museum building was not seen to be making a derivative work of the museum building because it did not affect the copyright attached to the architect of the building. Because the object of the photograph, the museum building, can be seen from a public place and because the act of taking the photograph was not seen as something against the objective of copyright law, the Court concluded that Gentile's photograph was an "artistic expression protected by the First Amendment". ${ }^{111}$ The photograph was protected as a new artistic work, and the author of it had exclusive rights over it, including the right to gain commercial advantage from it.

If this case is viewed in relation to Title 17 USC $\S 120(a)$, then it can be concluded that taking photographs of architectural works is protected in the United States, provided that part of the structure being photographed is located in, or visible from, a public place. The case above also concluded that exclusive rights are attached to such photographs, and therefore that is the authors of the photographs have right to commercialise them. The right to commercialise such photographs was therefore protected in the United States even before enactment of Title 17 USC $\S 120$ (a). Based on Title 17 USC $\S 101$ and $\S 106 \mathrm{~A}$, architects in the United States do not have their moral rights protected in that form, although they are acknowledged to hold copyright

\footnotetext{
${ }^{108}$ The Rock and Roll Hall of Fame and Museum, Inc, et al v Gentile Productions, et al 134 F 3d 749 (6th Cir 1998).

${ }^{109}$ At 758.

${ }^{110}$ The Rock and Roll Hall of Fame and Museum, Inc, et al v Gentile Productions, et al 71 F Supp 2d 755 (ND OH 1999) at 759.

${ }^{111}$ At 760 .
} 
protection and to have the right to exercise their exclusive rights. Architects are the authors of their building but not the authors of photographs of their works. The photographs are new artistic works, and therefore the photographers have exclusive rights over their photographs, including the right to gain commercial advantage from them.

However, a different approach applies to photographs of sculptural works, even to works permanently situated in public places. This approach can be seen in the case of Gaylord v United States. ${ }^{112}$ The case concerned Frank Gaylord, who was selected as the sculptor for the Korean War Veterans Memorial in Washington DC in 1986. He began to work on sculpting 19 stainless-steel statues of soldiers in 1990 and completed work on them in 1995. Between 1990 and 1995, Gaylord had registered copyright on various versions of the sculptures, which acknowledged Gaylord as the author of them. In 1996, an amateur photographer named John Alli took photographs of the statutes, with one of them being described as a "particularly haunting, ghostlike photo of the snow-covered steel soldiers". It was known that Alli initially intended that the photographs were for personal use. ${ }^{113}$

However, in 2002, the United States government paid Alli an amount of money for the right to use the photograph of the snow-covered soldiers on a 37-cent postage stamp. The United States Postal Service gained more than $\$ 17$ million from sales of the stamp. In 2006, after he had learned that others had gained commercial advantage from photographs of his works taken without his consent, Gaylord filed a suit against the United States Postal Service for copyright infringement in the United States Court of Federal Claims. In 2008, the Court of Federal Claims found that, although Gaylord was acknowledged as the sole copyright owner of the sculptures ${ }^{114}$, the government's use of the sculpture on the stamp constituted fair use and determined that the photograph had "a new and different character and expression than Mr. Gaylord's [work]"115.

That judgment was debated at the Court of Appeals in 2010. The Court found that the government's stamp was not a fair use as the Postal Service had gained commercial advantage from the use of the photograph. ${ }^{116}$ Other than that, the sculpture, named "The Column" in the judgments, is not an architectural work under Title 17 USC $\S$ 120. That means that others do not have the right to make pictorial representations of

\footnotetext{
${ }^{112}$ Gaylord v United States 678 F 3d 1339 (DC Cir 2012).

${ }^{113}$ Gaylord v United States $85 \mathrm{~F} \mathrm{Cl} 59$ (DC Cir 2008) at 64."Alli intended the picture to be a retirement gift for his father, who served in the Marine Corps in Korea."

${ }^{114}$ At 62 .

${ }^{115}$ At 69

${ }^{116}$ Gaylord v United States 595 F 3d 1364 (DC Cir 2010) at 1376.
} 
Gaylord's work under Title 17 USC, and that Gaylord was entitled for determination of damage, despite having a dissenting opinion that the sculpting has been "paid for by appropriated funds". ${ }^{117}$ The other subsequent judgments ${ }^{118}$ related to this case were only a matter of determination of damages without any further questions regarding the use of the photograph of the sculpture.

It is clear that sculptural works are not included in the freedom of panorama in the United States, and therefore photographers are not allowed to take photographs of copyright-protected sculptures without first gaining the consent from the sculptors, even when the sculptures are permanently situated in or visible from public places. The judgment in Gaylord v United States makes it clear that any unauthorised person is not allowed to take photographs of sculptures in public places in order to gain commercial advantage from them. The only exception for this provision is "fair use". ${ }^{119}$ For example, if photographs of copyright-protected sculptures situated in public places are used for educational purposes and with no intention to gain profit from the use, then the use of the photographs may fall under fair use under the Title 17 and therefore does not constitute a copyright infringement action.

\section{New Zealand \\ $1 \quad$ Exclusive Rights}

The New Zealand Copyright Act 1994 includes similar rights to the exclusive rights mentioned by Title 17 USC, but has a wider scope. Article 16 of the Act provides that the exclusive rights include the following acts: ${ }^{120}$

The owner of the copyright in a work has the exclusive right to do, in accordance with sections 30 to 34, the following acts in New Zealand:

(a) to copy the work ${ }^{121}$;

\footnotetext{
117 At 1381. The Army Corps of Engineers selected Cooper-Lecky Architects, P.C. as the prime contractor for the creation, construction, and installation of the Korean War Veterans Memorial and followed by Cooper-Lecky sponsored a competition to select the sculptor for the Memorial in which Gaylord was chosen as the winner and receive payment for making sculptures for the Memorial.

118 Gaylord v United States 98 Fed Cl 389 (DC Cir 2011) awards damages of \$5,000 to Gaylord, Gaylord v United States 678 F 3d 1339 (DC Cir 2012) remanded the case, and the latest Gaylord v United States 2013 WL 5290438 awards damages of $\$ 684,844.94$ to Gaylord.

${ }^{119}$ Copyright Act 17 USC $\S 107$. To determine whether the use of a copyright-protected work is under fair use, the factors that should be considered are the purpose of the use, the nature of the work, the portion of the work that is being used, and the effect of the use in relation to the possibility of gaining commercial advantage.

${ }^{120}$ Copyright Act 1994, s 16.

121 Though the owner of copyright has the exclusive right to make copies of his works, it is acknowledged in New Zealand Copyright Act 1994 that making copies of copyright-protected works is
} 
(b) to issue copies of the work to the public, whether by sale or otherwise;

(c) to perform the work in public;

(d) to play the work in public;

(e) to show the work in public;

(f) to communicate the work to the public;

(g) to make an adaptation of the work;

(h) to do any of the acts referred to in any of paragraphs (a) to (f) in relation to an adaptation of the work;

(i) to authorise another person to do any of the acts referred to in any of paragraphs (a) to (h).

It is not necessarily a breach of copyright if someone uses the copyright-protected works by doing acts other than those stated above, the "restricted acts" that can only be taken by the copyright owner. For example, it is not an infringement of copyright to buy a copy of a stage play, but it would be an infringement to perform the play without gaining permission from the copyright owner. ${ }^{122}$ However, using a copyrightprotected work to gain commercial advantage without the copyright holder's permission is an act of copyright infringement. ${ }^{123}$

\section{$2 \quad$ Freedom of Panorama}

The basic concept of the freedom of panorama is the provision of legal protection for people who take photographs of copyright-protected works that are permanently situated in public places without as an assessment as to whether there has been a copyright infringement of those works having taken place. Based on this concept, the freedom of panorama is provided for under s 73 of the New Zealand Copyright Act 1994, as follows: ${ }^{124}$

(1) This section applies to the following works:

(a) buildings:

not infringing the copyright so long as the making of copies is intended for personal use in the case of copying sound recordings under art $81 \mathrm{~A}$ of the Act.

${ }_{122}$ Paul Sumpter Intellectual Property Law: Principles in Practice (2nd ed, CCH New Zealand Limited, Auckland, 2013) at 201.

${ }^{123}$ Exclusive rights that are protected in the United States, New Zealand, and Indonesia include the right to gain commercial advantage. Based on this provision, if others would like to gain commercial advantage from a copyright-protected work, they should obtain the copyright holder's permission to do so. See Copyright Act 17 USC § 106, s 16 of New Zealand Copyright Act 1994, and art 2(1) Indonesian Copyright Law 2002.

${ }^{124}$ Copyright Act 1994, s 73. 
(b) works (being sculptures, models for buildings, or works of artistic craftsmanship ${ }^{125}$ ) that are permanently situated in a public place or in premises open to the public.

(2) Copyright in a work to which this section applies is not infringed by-

(a) copying the work by making a graphic work representing it; or

(b) copying the work by making a photograph or film of it; or

(c) communicating to the public a visual image of the work.

(3) Copyright is not infringed by the issue to the public of copies, or the communication to the public, of anything the making of which was, under this section, not an infringement of copyright.

In comparison to the New Zealand Copyright Act 1994, the copyright law of the United Kingdom also provides for the freedom of panorama. In s 62 of the United Kingdom Copyright, Designs and Patents Act 1988, it is stated that the copyright in buildings and sculptures, if permanently situated in a public place or in premises open to the public, ${ }^{126}$ is not infringed upon by making a photograph of it. ${ }^{127}$ However, there is no explanation found in the New Zealand Hansard ${ }^{128}$ of debate on the enactment of s 73 of the New Zealand Copyright Act 1994.That section was not debated in detail during the first, second and third reading on the legislation. It is therefore not clear why this Act made an exception to copyright infringement in relation to the making of, among others, photographs of works that are permanently situated in public places, apart from the fact that the New Zealand Copyright Act 1994 was heavily based on the United Kingdom Copyright, Designs and Patents Act 1988.

Section 73 of the New Zealand Copyright Act 1994 is similar to Title 17 USC $\S$ 120(a) in terms of providing protection for exercising the freedom of panorama. Nevertheless, there is an obvious difference between these provisions. Section 73 of the Act provides protection for the taking of photographs of architectural and

\footnotetext{
${ }^{125}$ There is no further explanation on "work of artistic craftsmanship", for example if this also means the murals on the wall of a building. However, Justin Graham defines a work of artistic craftsmanship as a work which does not meet any of the other types of protected artistic works. See Justin Graham "New Zealand" in Ben Allgrove (ed) International Copyright Law: A Practical Global Guide (Globe Law and Business, London, 2013) 379 at 382. Susy Frankel summarised s 73 as a provision that allows anyone to make a graphic work, photographs, and film of "buildings or works on public display" so long as the mentioned works are "permanently on public display or in premises open to the public". See Frankel, above n 19, at 5.5.4.

${ }^{126}$ Copyright, Designs and Patents Act 1988 (UK), s 62(1).

${ }^{127}$ Section 62(2).

${ }^{128}$ Section 73 of the New Zealand Copyright Act 1994 was made in reference to s 62 of the United Kingdom Copyright, Designs and Patents Act 1988. The Whitford Report did not show that the United Kingdom hansard on this Act has an explanation as to why the act of making a graphic work, photograph, film, and visual image of the mentioned works that which are permanently situated in public places is allowed. The reason behind this provision is most probably for a practical reason that the law could not control the public place and to avoid confusions on copyright protection of the photographs and the depicted works.
} 
sculptural works, while Title 17 USC $§ 120$ (a) only provides protection for the taking photographs of architectural works only. Other than the difference in the type of copyright-protected works allowed to be photographed, Section 73 of the Act provides protection only if the depicted architectural and sculptural works are permanently situated in public places. Title 17 USC $\S 120$ (a) provides protection for photographs of architectural works if the works are located in, or visible from, public places.

\section{$3 \quad$ Moral Rights in the Freedom of Panorama}

Section 94(1) of the New Zealand Copyright Act 1994 provides that the author of an artistic work that is a copyright work has the right to be identified as the author of the work. ${ }^{129}$ This means that a photographer has the right to be identified as the author of the photographic works. However, in relation to the freedom of panorama, the photographer is not automatically identified as the author of the photographs.

Michalos stated that, referring to the Copyright Law of the United Kingdom, if a photograph of an architectural work or a sculpture is issued to the public, then the author of the work depicted has the right to be identified as the author of the photograph. ${ }^{130}$ This condition applies in New Zealand, as s 94(6) of the New Zealand Copyright Act 1994 stated as follows: ${ }^{131}$

The author of an artistic work has the right to be identified as the author of the work whenever-

$\cdots$

(e) in the case of a sculpture, a work of architecture in the form of a building or a model for a building, ... or of a photograph of the work, are issued to the public.

Therefore, based on the provision stated above, the publication of photographs taken under the freedom of panorama in New Zealand should include the architects' or the sculptors' names as the authors of the depicted works. In addition to the right to be acknowledged as the author, under Part 4 of New Zealand Copyright Act 1994 about moral rights, there is a right to object to derogatory treatment of work. The "treatment" mentioned in s 98 of the Act is limited to: ${ }^{132}$

\footnotetext{
${ }^{129}$ Section 94(1).

${ }^{130}$ Christina Michalos The Law of Photography and Digital Images (Sweet \& Maxwell Ltd, London, 2004) at 165.

${ }^{131}$ Copyright Act 1994, s 94(6) (emphasis added).

132 Section 98(1).
} 
(a) the term treatment of a work means any addition to, deletion from, alteration to, or adaptation of the work, other than-

(i) a translation of a literary or dramatic work; or

(ii) an arrangement or transcription of a musical work involving no more than a change of key or register; and

(b) the treatment of a work is derogatory if, whether by distortion or mutilation of the work or otherwise, the treatment is prejudicial to the honour or reputation of the author or director.

The authors of copyright-protected works have the right not to have their works subjected to derogatory treatment. ${ }^{133}$ Therefore, in relation to the freedom of panorama, architects and sculptors have the right not to have their photographs subjected to derogatory treatment. The right to object to derogatory treatment is considered infringed upon if a person "issues to the public copies of a photograph of a derogatory treatment of the work". ${ }^{134}$

One case that relates to this discussion is Radford $v$ Hallenstein Bros Ltd. ${ }^{135}$ Radford was a sculptor and three of his works were permanently situated in a public park in Auckland. Without gaining prior consent from Radford, Hallenstein Bros Ltd paid a photographer and sold t-shirts displaying photographic prints of two out of the three Radford's sculptures. Radford objected to that and bought a claim to the District Court alleging copyright infringement. Radford alleged three causes of action, stated by Judge Hubble as follows: ${ }^{136}$

First, breach of economic rights, pursuant to s 29, 30, and 31 of the Copyright Act 1994. Secondly, breaches of s 35 and s 36 of the Copyright Act for importing t-shirts and, thirdly, a breach of moral rights, pursuant to s 99 of the Act.

Radford's claim of a breach of moral rights was based on the issue of derogatory treatment. As a sculptor, Radford, under s 94(6)(e) of the New Zealand Copyright Act 1994, had the right to be identified as the author of the works in the photographic prints of his works. At the same time, altering the photographs to be printed on tshirts could be seen as derogatory "treatment" as defined in s 98(1)(a) of the Act.

\footnotetext{
${ }^{133}$ Section 98(2)(a).

${ }^{134}$ Section 99(2)(c).

${ }^{135}$ Radford v Hallenstein Bros Ltd [2009] DCR 907. At 13, it was mentioned in the judgment that this provision about derogatory treatment under New Zealand Copyright Act 1994 was mandated by art 6bis(1) of the Berne Convention which provides that "Independently of the author's economic rights, and even after the transfer of the said rights, the author shall have the right to claim authorship of the work and to object ... derogatory action in respect to the said work ..." (Emphasis added).

${ }^{136}$ Radford $v$ Hallenstein Bros Ltd DC Auckland CIV-2005-004-3008 (17 July 2006) at 1.
} 
Based on that reasoning, Radford had the right to object to the making of the printed t-shirts because he had a right to object to such a treatment.

It was stated in the judgment in relation to the issue of asserting infringement of moral rights that "there was no element of addition, deletion, alteration or adaptation relating to the sculpture itself"137 as the act of printing the photograph on the t-shirt was "a treatment to a treatment". The first "treatment" that happened directly to the sculpture was the act of taking the photograph, which was legally allowed under s 73 of the New Zealand Copyright Act 1994. The second "treatment" was the printing of the photograph of the sculpture on the t-shirt, which did not offend the moral rights attached to the sculpture. However, Judge Roderick Joyce decided that "the application must be dismissed". ${ }^{138}$

The judgment on that particular issue in the case was inconclusive. The provision in $\mathrm{s}$ 94(6) of the New Zealand Copyright Act 1994 meant that a sculptor has the right to be identified as the author of a sculptural work whenever a photograph of his work is issued to the public. Therefore, Radford should be named as the author of the photographed sculpture in any photograph of it.

\section{Economic Rights in the Freedom of Panorama}

The issue of unauthorised commercial exploitation of copyright-protected works has often been debated in copyright law cases in New Zealand. ${ }^{139}$ In relation to the freedom of panorama, s 73(3) of the New Zealand Copyright Act 1994 stated that copyright is not infringed by the issue to the public of copies of anything the making of which was, under s 73 of the Act, not an infringement of copyright. It is not unclear whether the issue of copies stated in s 73(3) of the Act includes by means of selling, but s 16(1) of the Act provides that it is the exclusive rights of the copyright owner "to issue copies of the work to the public, whether by sale or otherwise" looking at s 16(1) of the Act, photographs that are taken under the freedom of panorama can only be issued for sale by the copyright owner of the photographs.

\footnotetext{
${ }^{137}$ Radford v Hallenstein Bros Ltd [2009] DCR 907 at 33.

${ }^{138}$ At 113. As the discussion was decided to being dismissed, there was no clear conclusion on whether the t-shirt makes a derogatory treatment to the sculpture or not.

${ }^{139}$ The example of cases in unauthorised commercial exploitation, although not related to the freedom of panorama, are G-Star Raw C.V. v Jeanswest Corporation (NZ) Ltd [2013] NZHC 1251, Oraka Technologies Ltd v Geostel Vision Ltd [2013] NZCA 111, and United States of America v Dotcom [2013] 2 NZLR 139.

${ }^{140}$ Copyright Act 1994, s 16(1)(b).
} 
The previous discussion about moral rights in the freedom of panorama in New Zealand concluded that architects and sculptors have the right to be identified as the authors of copyright-protected works in photographs taken under the freedom of panorama. However, because they are recognised as the authors of the original works does not necessarily mean that they are also the copyright owners of the photographs. Also, the architects or the sculptors do not necessarily obtain exclusive rights, including the right to commercialise photographs of their works.

Radford v Hallenstein Bros Ltd ${ }^{141}$ relates directly to the question as to whether others can legally gain commercial advantage from a photograph of a copyright-protected sculpture that is permanently situated in a public place. The discussion in this case primarily focused on the interpretation of s 73. Judge Keane at the High Court of Auckland interpreted the provision as follows: ${ }^{142}$

To the extent that s73 speaks it does so plainly. It sets out to allow members of the public, including players in the market, to copy in two-dimensions sculptures permanently in the public domain and even for profit. It does so by setting aside any copyright in the work that the author might otherwise enjoy. However s 73 is interpreted, that clear policy is not for compromise.

Judge Keane's opinion was in line with the opinion of Judge Hubble in the Auckland District Court. Keane believed that the New Zealand Copyright Act 1994 did not prevent a person from gaining commercial advantage from the photographs of sculptures permanently situated in public place: ${ }^{143}$

... the vast weight of academic opinion and practical implementation of $\mathrm{s} 73$ favours the view that the words "issued to the public" does not prevent commercial exploitation in the form of photography, drawings, post cards and printing onto items of clothing. I can see no legal basis for the contrary argument and no prospect that it would succeed under the present legislation.

Whether the publication of the photograph should in any way mention Radford as the author of the sculpture was not debated. However, various judgments make it clear that commercialising photographs taken under the freedom of panorama is protected under s 73 of the New Zealand Copyright Act 1994.

\footnotetext{
${ }^{141}$ Radford v Hallenstein Bros Ltd [2009] DCR 907.

${ }^{142}$ Radford v Hallenstein Bros Ltd HC Auckland CIV-2006-404-4881 (22 February 2007) at 35 (emphasis added).

${ }^{143}$ Radford v Hallenstein Bros Ltd DC Auckland CIV-2005-004-3008 (17 July 2006) at 29.
} 


\section{Indonesia \\ $1 \quad$ Exclusive Rights}

Both Title 17 USC and the New Zealand Copyright Act 1994 list the acts that are considered to be protected because of exclusive rights within the main text of the legislation, as Title 17 USC and New Zealand Copyright Act 1994 are applicable without an "elucidation". It is different from Indonesian Copyright Law 2002, where "copyright shall mean the exclusive right of an author or a copyright holder to publish or reproduce the copyright-protected works" 144 in the main text of the Law, but then the list of acts are mentioned in the Elucidation of the Law. There is no legal implication on having separate Elucidation from the body of the Law in Indonesia, as the Law and its Elucidation are applicable as a single piece of legislation, and elucidations should provide further explanations if there is a doubt in interpreting the main text of the laws, though that is not always the case. ${ }^{145}$ Based on the Elucidation of the Law, the exclusive rights "to publish or reproduce" shall include the following acts: ${ }^{146}$

... [to] translate, adapt, arrange, transform, sell, hire, lend, import, display, perform in public, broadcast, record, and communicate the Works to public in any means.

The lists of acts that fall under exclusive rights in Indonesia are similar to the exclusive rights in Title 17 USC and the New Zealand Copyright Act 1994.

\section{Unauthorised Use of Copyright-Protected Works and the Freedom of Panorama}

Photographic works are protected under the Indonesian Copyright Law 2002 as artistic works and the photographers' copyright of the works is protected for up to 50 years after the works are made available to public. ${ }^{147}$ The term of protection for photographic works under the Law is different from the term for some other copyrightable works, such as architectural and sculptural works, which last for 50

\footnotetext{
${ }^{144}$ Indonesian Copyright Law 2002, art 2(1).

${ }^{145}$ Legal professionals in Indonesia often feel that there are some provisions in Indonesian Law that require further explanation, but its elucidations only stated "sufficiently clear". In this case, the legal professionals are customarily allowed to introduce their interpretations with supporting evidence. Judges are allowed to have their interpretations based on their findings on trials and also based on "what they think is the best interpretation".

${ }^{146}$ Elucidation of Indonesian Copyright Law 2002, art 2(1).

${ }^{147}$ Indonesian Copyright Law 2002, art 30. The Elucidation of the Law for this provision does not provide further explanation.
} 
years after the authors' death. ${ }^{148}$ However, there is an exception for the use of photographic works, which do not require prior permission from the authors of copyright-protected works. Article 23 of the Indonesian Copyright Law states: ${ }^{149}$

Unless agreed otherwise between the Copyright Holder ${ }^{150}$ and the Owner ${ }^{151}$ of a creative work in the form of a photograph, painting, drawing, architecture, sculpture and/or other artworks, the Owner shall be entitled to without the consent of the Copyright Holder to display the work in a public exhibition or to reproduce it in a catalogue, without detracting from the provisions of Article $19^{152}$ and Article $20^{153}$ if said work of art is in the form of a portrait.

Based on the provision above, it is possible for other people beside the authors of copyright-protected works to display or reproduce photographic works, although in a very limited manner. Those who can do such actions under the Law are "the Owners" of the photographic works. The actions are only limited to displaying the works in a public exhibition or reproducing them in a catalogue, and therefore prohibit others to do any actions that are not listed above. The type of photographic works that are included in this provision is not limited to "portraits" 154 , but this provision and art 23

\footnotetext{
${ }^{148}$ Article 29. The Elucidation of the Law for this provision does not provide further explanation.

${ }^{149}$ Article 23 (emphasis added). The Elucidation of the Law for this provision does not provide further explanation.

${ }^{150}$ Article 1 no. 4 stated that "Copyright Holder" means "the Author as the Owner of the Copyright, or any person who receives the right from the Author, or any other person who subsequently receives the right from the aforesaid person".

${ }^{151}$ There is no definition of "Owner" in the body of the Indonesian Copyright Law 2002. However, art 15(a) in the Elucidation of Indonesian Copyright Law 2002 provides a sentence that stated "An owner (not a Copyright Holder) ..." Based on this sentence, it can be concluded that an owner is a person who holds the copyright-protected works but does not automatically have copyright over the works. The explanation about "Owner" and copyright over the works that he hold, relates to art 26(1) of the Indonesian Copyright Law 2002 which provides that "Copyright of a Work shall remain in the hands of the Author as long as the entire Copyright is not transferred to the purchaser of the Work". However, in the case where there is a dispute between purchasers of the same copyright of a work, the protection shall be granted to the purchaser who first obtained the copyright, as stated in art 26(3) of the Indonesian Copyright Law 2002.

${ }^{152}$ Article 19 of the Indonesian Copyright Law 2002 only applies to a portrait which is made "at the request of the person portrayed, upon a request made on behalf of the person portrayed, or in the interest of the person portrayed". In this case, the Copyright Holder of the portrait should obtain prior permission from the portrayed person to reproduce or to publish the portrait. If the portrait contains more than one person, the Copyright Holder should obtain the permission from each of the portrayed person.

${ }^{153}$ Article 20 of the Indonesian Copyright Law 2002 stated that "the Copyright Holder on a portrait shall not be allowed to publish the portrait, which was taken: a. without the consent of the person portrayed; b. without the consent of another person on behalf of the person portrayed; or c. not for the interest of the person portrayed, if the publication is contrary to the normal interest of the person portrayed, or if that person has died, the normal interest of one of his heirs".

${ }^{154}$ Article 1 no. 7 stated that portrait means "any picture taken by whatever means and with whatsoever equipment portraying the face of a person together with or without other parts of the body". This provision only limits the use of portrait should not violate art 20 of the Law, therefore stating "without detracting from the provisions of ... Article 20 if said work of art is in the form of a portrait”.
} 
of the Elucidation of Indonesian Copyright Law 2002 does not state whether photographs of architectural or sculptural works are not excluded from it.

There is no similar limitation available in either the copyright laws of the United States or New Zealand, as the Indonesian Copyright Law 2002 did not clearly state that the freedom of panorama was available in Indonesia. However, that does not mean that the freedom of panorama is prohibited under the Indonesian Copyright Law. Unauthorised use of copyright-protected works allowed under the Law, other than the one provided for in art 23 of the Law, is "fair use", ${ }^{155}$ and the freedom of panorama is not included or even mentioned in that exception. That may confuse some people who are interested in taking photographs of architectural and sculptural works in public places in Indonesia as to whether they would infringe the architects and sculptors' copyright and whether they can own copyright over their photographs. One of the downsides of this confusion was made evident when Wikimedia Commons, one of the largest information resources on the internet, decided to delete pictures of architectural and sculptural works in Indonesia, including those of works permanently situated in public places. ${ }^{156}$

\section{$3 \quad$ Protection of Moral Rights}

The preamble of the Elucidation section in Indonesian Copyright Law 2002 stated that copyright consists of economic rights and moral rights. ${ }^{157}$ In contrast with Title 17 USC and New Zealand Copyright Act 1994, which provide that the protection of

\footnotetext{
${ }^{155}$ Article 15 of the Indonesian Copyright Law 2002 stated that: "Provided that the sources are fully cited, the following shall not be deemed as Copyright infringement:

a. the use of a work of another party for the purpose of education, research, scientific thesis, report writing, criticising or reviewing an issue, provided that it does not prejudice the normal interest of the Author;

b. the excerpt of a work of another party, in whole or in part, for the purposes of advocacy within or outside the court;

c. the excerpt of a work of another party, in whole or in part, for the purposes of: (i) lecturers of which the purpose is solely for education and science; or (ii) free-of-charge exhibitions or performances, provided that they do not prejudice the normal interests of the Author.

d. reproduction of a scientific, artistic and literary work in Braille for the purposes of the blind, unless such reproduction is of a commercial purpose;

e. limited reproduction of a work other than computer program limitedly by using any means whatsoever or by employing a similar process by a public library, scientific or educational institution and documentation centre of non-commercial nature, solely for the purpose of conducting their activities;

f. modification of any architectural works, such as building construction, based on consideration of technical implementation;

g. making of a back-up copy of a computer program by the owner of the computer solely for his own use."

${ }^{156}$ This information was obtained from Wikimedia Indonesia Chairwoman in 2012 and it affected some of Wikipedia articles about Indonesia. The problem is now solved with the understanding that the freedom of panorama is applicable in Indonesia under the legality principle.

${ }^{157}$ Elucidation of Indonesian Copyright Law 2002, preamble para 5.
} 
moral rights is different to copyright protection, the Indonesian Copyright Law 2002 provides that moral rights are protected as a part of the copyright protection of works. ${ }^{158}$ It is then explained in the Elucidation section that moral rights are rights that are attached to the authors or performers, and they cannot be denied or waived for any reason, although the copyright or related rights have been transferred, which makes the provision quite similar to the provisions in the United States and New Zealand. ${ }^{159}$ For the purpose of a discussion regarding copyright protection for photographic, architectural, and sculptural works in Indonesia, a reference to the definition of an author is available in art 1 of the Indonesian Copyright Law 2002. It is defined as follows: ${ }^{160}$

2. Author shall mean a person or several persons jointly upon whose inspiration a Work is produced, based on the intellectual ability, imagination, dexterity, skill or expertise manifested in a distinctive form and is of a personal nature.

Basically, moral rights are protected and attached to the authors of copyrightprotected works until the end of the term of protection. Based on that statement, the Indonesian Copyright Law 2002 provides a provision related to the protection of moral rights that also includes a similar provision to the right to object to derogatory treatment in s 98 of the New Zealand Copyright Act 1994 and Title 17 USC $\S$ 106A(a)(3)(A). Article 24 of the Indonesian Copyright Law 2002 on the protection of moral rights states that: ${ }^{161}$

(1) An Author or his heir shall be entitled to require the Copyright Holder to attach the name of the Author on his work.

(2) It is forbidden to make changes to a Work although the Copyright has been transferred to another party, except with the consent of the Author or his heir if the Author has been deceased.

(3) The provisions referred to in paragraph (2) shall also be applicable to changes in the title and subtitle of a work, inclusion and changes in the name or pseudonym of the Author.

(4) The Author shall remain entitled to make changes to his Work in accordance with social propriety.

\footnotetext{
${ }^{158}$ This provision also differs from art 6bis of the Berne Convention. Records of the Rome Conference of 1928, above n 53, showed that the Sub-committee on Moral Rights stated "Those rights, which for want of a more adequate expression are called moral rights, are distinguished from economic rights." which means there is a separation between moral rights and economic rights.

${ }^{159}$ Elucidation of Indonesian Copyright Law 2002, preamble para 5.

${ }^{160}$ Indonesian Copyright Law 2002, art 1 The Elucidation of the Law for this provision does not provide further explanation. This provision is very similar to ss 5 to 6 of the New Zealand Copyright Act 1994.

161 Article 24.
} 
With moral rights, an author of a copyrighted work has the right to have his or her name or pseudonym in his or her work or a copy of the work. An author also has the right to object to any forms of distortion, mutilation, or other alterations of his or her work, including the twisting, cutting, or destruction of it, associated with the replacement of the copyright-protected work, which will eventually damage the reputation and appreciation of the author. ${ }^{162}$ However, the term of protection for the moral rights differs based on the attribution given to the authors. In the case of art 24(1) of the Indonesian Copyright Law 2002, no time limit is prescribed. It does not even cease after the term of the copyright protection ends. ${ }^{163}$ In the case of arts 24(2) and 24(3) of the Indonesian Copyright Law 2002, the term of protection is the same period of the given copyright protection, except for the identification and changing of the name or pseudonym of the author. ${ }^{164}$

Based on the provision in art 2(1) of the Elucidation of the Indonesian Copyright Law 2002 , the act of taking photographs of architectural and sculptural works may be considered to be an adaptation of the works into a two-dimensional form, and therefore the act cannot be conducted without gaining prior permission from the architects and the sculptors. However, legal professionals believe that this is not a legal issue and that there is no case law that challenges the freedom of panorama. This means that the photographers who take photographs under the freedom of panorama have the right to be acknowledged as the authors of the photographs.

\section{$4 \quad$ Protection of Economic Rights}

It states in the preamble of the Elucidation of the Indonesian Copyright Law 2002 that copyright consists of economic rights and moral rights. It is explained that economic rights consist of the rights to gain commercial advantage from the works and other products related to the works. ${ }^{165}$ In the fair use provisions under the Indonesian Copyright Law 2002, it is provided that unauthorised use should be in balance with the authors' or copyright holders' right to enjoy commercial advantage from the works. ${ }^{166}$ Legal professionals believe that this is not a legal issue, and the lack of case law that challenges the freedom of panorama means that the photographers who take photographs under the freedom of panorama, aside from being recognised as the author of the photographs, are able to exercise exclusive rights over them.

\footnotetext{
${ }^{162}$ Elucidation of Indonesian Copyright Law 2002, art 24(2).

${ }^{163}$ Indonesian Copyright Law 2002, art 24(1).

${ }^{164}$ Indonesian Copyright Law 2002, art 24(2) and 24(3).

${ }^{165}$ Elucidation of Indonesian Copyright Law 2002, preamble para 5.

${ }^{166}$ Elucidation of Indonesian Copyright Law 2002, art 15(a).
} 
The freedom to take photographs of architectural and sculptural works exists in the United States, New Zealand, and Indonesia. However, to gain copyright protection for such photographs, the United States and New Zealand have clearer provisions under their copyright laws than does the Indonesian Copyright Law 2002. Although both of the United States and New Zealand have provisions that satisfy the definition of the freedom of panorama according to Newell's argument ${ }^{167}$, the United States has a more limited definition of the freedom of panorama, which only covers the rights to photograph and commercialise ${ }^{168}$ photographs of architectural works. In New Zealand, the freedom of panorama covers the right to photograph and commercialise photographs of architectural and sculptural works. Both of the United States and New Zealand provisions are supported by one or two cases. However, not many cases have appeared to debate the provisions related to the freedom of panorama, though the provision in the United States only limits the freedom to taking photographs of architectural works. This means that if the case of Radford $v$ Hallenstein Bros Ltd ${ }^{169}$ took place in the United States, it is probable that the use of photographs of Radford's statues by Hallenstein would be considered as infringing Radford's copyright and would result in a different judgment from what it was decided in New Zealand.

In Indonesia, the freedom to photograph and commercialise photographs of architectural and sculptural works is considered allowed and protected under the Indonesian Copyright Law 2002 according to the logical applicability of the "legality principle" 170 . As there is no provision under the Indonesian Copyright Law 2002 that prohibits the taking photographs of copyright-protected works and the commercialisation of such photographs, photographs taken under the freedom of panorama in Indonesia are protected in the same way as other photographic works. However, other people without *proper comprehension of the Indonesian legal

\footnotetext{
${ }^{167}$ Newell, above n 1, at 409.

${ }^{168}$ The Rock and Roll Hall of Fame and Museum, Inc, et al v Gentile Productions, et al, above n 107.

${ }^{169}$ Radford v Hallenstein Bros Ltd [2009] DCR 907. At 13, it was mentioned in the judgment that this provision about derogatory treatment under New Zealand Copyright Act 1994 was mandated by art 6bis(1) of the Berne Convention which provides that "Independently of the author's economic rights, and even after the transfer of the said rights, the author shall have the right to claim authorship of the work and to object ... derogatory action in respect to the said work ..." (Emphasis added).

${ }^{170}$ The legality principle phrase in Indonesia is "nullum delictum nulla poena sine praevia lege poenali" which means that no offence can be prosecuted and no law can be implemented without any legislation applies to the circumstances. This principle is written in Article 1(1) of the Indonesian Criminal Code. This principle is also known as "non-retroactive" principle in Indonesia, which means that the updated legislations could not be applied to any previous "unlawful" circumstances. Though Indonesian legal system adopts the civil law system and codified law through what is known as "European continental legal system" influence in Indonesia, this principle is a prove that there is also common law system influence over Indonesian legal system.
} 
system* might argue that the freedom of panorama does not exist in Indonesia, because it is not explicitly mentioned in the Indonesian Copyright Law 2002.

\section{Comparison to Photographs of "Public Domain Works"}

Copyright protection is automatically given to literary and artistic works. However, that protection is limited to a "term of protection" "171. If the term of protection has come to an end, the works are available for everyone to use freely and without permission. Literary and artistic works that are no longer protected by copyright fall into the category of "public domain works". ${ }^{172}$ The phrase "public domain" means that the use of those works are no longer limited by exclusive rights and that the works may be freely used by others, and that, therefore, the "former" copyright owners of the works cannot prohibit others to do any actions to the works or require others to gain prior consent from the authors. In other words, the public owns these works, and while anyone can use a public domain work without obtaining permission, no one can own copyright over a public domain work. ${ }^{173}$

In the United States, literary or artistic works fall under the "public domain" not only after the term of copyright protection has expired, but also where the author failed to satisfy statutory formalities required for the work to be protected or where the work is a work of the US government. In New Zealand, the term "public domain" refers to not only materials in which its copyright protection has expired, but also to materials "where the copyright owner has given very broad permissions to people to use it". ${ }^{174}$

\footnotetext{
${ }^{171}$ In the copyright laws of the United States and New Zealand, provisions regarding the term of protection are available under the "Duration of Copyright" section. In the Indonesian Copyright Law 2002, the provision is available under "Copyright Validity" section. Under arts 22 to 25 of the New Zealand Copyright Act 1994, copyright protection for literary and artistic works expire "at the end of the period of 50 years from the end of the calendar year in which the author dies" with some exceptions, for example, "if the work is computer-generated, copyright expires at the end of the period of 50 years from the end of the calendar year in which the work is made". Under ss 302 to 305 of Copyright Act 17 United States Code, "copyright subsists from its creation and, except as provided by the following subsections, endures for a term consisting of the life of the author and 70 years after the author's death" with some exceptions, for example protection for copyright-protected works created before 1 January 1978 on its first term of protection "shall endure for 28 years from the date it was originally secured". Under arts 29 to 34 of the Indonesian Copyright Law 2002, copyright protection "shall be valid for the life of the authors and 50 years after his death", with some exceptions such as for photographic works, protection is only given for 50 years from the date of its first publication.

${ }^{172}$ For the purpose of this paper, "public domain works" means the works that are no longer protected under copyright.

173 “"Welcome to the Public Domain” Copyright \& Fair Use”, Stanford University Libraries <http://fairuse.stanford.edu>.

${ }^{174}$ Copyright Council of New Zealand "Public domain - What does "public domain" refer to?" <http://www.copyright.org.nz>.
} 
Permissible actions in respect of public domain works include making a copy, adaptation, or derivative work through any means, including for commercial purposes. In Indonesia, moral rights over public domain works are recognised and the practice requires users of well-known public domain works to mention their authors ${ }^{175}$ but there is more freedom for others to use public domain works.

\section{A Adaptation or Derivative Works of Public Domain Works}

Because others are allowed to use public domain works without any restrictions, it is impossible to limit the actions that can be done in respect of such works. Aside from people being allowed to copy and reproduce the works, people are allowed to make derivative works based on public domain works without having to gain prior consent from the authors. It is well-known in some countries, such as the United States, New Zealand, and Indonesia ${ }^{176}$, that derivative works or adaptations of copyright-protected works are also protected under copyright law. However, the question remains as to whether adaptations or derivative works of public domain works are also protected under copyright law. There is also the question as to whether the protection differs from general copyright protectionfor example, whether the protection is different when the original work is already in the public domain.

In the United States, the changes made to the original work are protected in a derivative work. ${ }^{177}$ The protection for those changes is not affected by the protection of the original work, and vice versa. The relevant provision also applies to derivative works of public domain works, where the changes to the derivative works are protected as new works but the original works are not protected by copyright. Others could freely use the original works, but not the derivative works. ${ }^{178}$

In New Zealand, an adaptation is protected under copyright and its existence is not considered as a copyright infringement of the original work. ${ }^{179}$ That provision signifies that the protection for adaptation is separated from the protection for the original work, and therefore the condition of protection for the original work will not affect copyright protection of the adaptation. A similar provision applies in Indonesia through arts 12(1)(1) and 29(1)(j) of the Indonesian Copyright Law 2002.

\footnotetext{
${ }^{175}$ Part Seven of the Indonesian Copyright Law 2002 regarding moral rights does not state this and the recognition only works in practice.

${ }^{176}$ Copyright Act 1994, s 92; Copyright Act 17 USC $§ \S 101$ and 103; and Indonesian Copyright Law 2002, art 12(1)(1).

${ }_{177}^{177}$ Copyright Act 17 USC $\$ 103(b)$.

178 United States Copyright Office "Copyright in Derivative Works and Compilations" <http://www.copyright.gov>.

${ }^{179}$ Copyright Act 1994, s 92.
} 
Based on the provisions of copyright laws in the three aforementioned countries, adaptations or derivative works are protected under copyright in the same way as original works. The protection for adaptations or derivative works is not dependent on the protection for the works that they are based on. In other words, there are two forms of copyright protection: protection for the original works and protection for adaptations or derivative works resultant of the original works. This means that even if the original works are already recognised as public domain works, adaptations or derivative works are protected with their own copyright.

\section{B Copyright Protection for Photographs of Public Domain Works}

The case of Burrow-Giles Lithographic Co $v$ Sarony $^{180}$ is a good introduction to any discussion about copyright protection for photographic works. In 1884, a photographer named Napoleon Sarony filed a copyright infringement suit against Burrow-Giles Lithographic Company. The Company had sold and tried to sell 85,000 unauthorised copies of Sarony's photograph of Oscar Wilde entitled "Oscar Wilde No. 18". ${ }^{181}$ The Company argued that copyright of the photograph could not be protected as the photograph did not qualify as "writings" or as the production of an "author", in reference to article I, section 8, clause 8 of the United States Constitution. ${ }^{182}$ Justice Miller from the Supreme Court stated in his judgment that photographs were considered to be original artistic works if they represented "original intellectual conceptions of the author" ${ }^{\prime 183}$. This judgment was based on the following acts that Sarony did to take the photograph: ${ }^{184}$

... posing the said Oscar Wilde in front of the camera, selecting and arranging the costume, draperies, and other various accessories in said photograph, arranging the subject so as to present graceful outlines, arranging and disposing the light and shade, suggesting and evoking the desired expression ...

Though there was an issue in the United States around the recognition of copyright protection for photographs, which was how the case of Burrow-Giles Lithographic Co $v$ Sarony arose, the issue concerning threshold of originality of photographs to gain copyright protection was not discussed.

\footnotetext{
${ }^{180}$ Burrow-Giles Lithographic Co v Sarony 111 US 53.

${ }^{181}$ At 54.

${ }^{182}$ At 56. It was also a question if s 4952 of the Copyright Act of 1870 was unconstitutional because it extended the protection to photographs although the wording on the Constitution only consisted of "writings".

${ }^{183}$ At 58 .

${ }^{184}$ At 54.
} 
Different but related cases occurred in the United Kingdom. Copyright protection for photographs would be given to photographs which were "original", and it was then a question as to whether photographs of copyright-protected works deserved to be protected. Graves' Case ${ }^{185}$, which was ruled on in English in 1869, found that taking photographs of a copyright-protected artistic work did not infringe the copyright of the depicted work, and that the photograph would be considered to be an original artistic work.

In that case, J B Walker was charged with infringing Henry Graves' copyright of several paintings and three photographs. The photographs were taken from three engravings made for Graves, in which the copyright of the engravings was owned exclusively by Graves, and those photographs were the only photographs of the engravings. Walker pointed out the issue of copyright protection for the photographs. Walker argued that the photographs were not original because it was merely copies for a work of art, and therefore the photographs were not protected. To solve this issue, s 1 of Fine Art Copyright Act 1862, which was the first to give copyright protection for photographs in English law, was referred to and was said to provide as follows: ${ }^{186}$

The author, being a British subject or resident within the dominions of the Crown, of every original painting, drawing, and photograph, ... shall have the sole and exclusive right of copying, engraving, reproducing, and multiplying such painting or drawing, and the design thereof, or such photograph, and the negative thereof, by any means and of any size ...

Based on the above provision, Graves had the right to take photographs of the engravings as he owned the copyright of the engravings. However, the photographs were only protected if there was proof that the photographs were original. In this matter, Justice Blackburn stated as follows: ${ }^{187}$

The distinction between an original painting and its copy is well understood, but it is difficult to say what can be meant by an original photograph. All photographs are copies of some object, such as a painting or a statue. And it seems to me that $a$ photograph taken from a picture is an original photograph, in so far that to copy it is an infringement of this statute.

Based on the judgment above, it can be concluded that, as photographs are recognised as artistic works, it should not be a problem to determine their originality. Each

\footnotetext{
${ }^{185}$ Graves' Case [1869] LR 4 QB 715.

${ }^{186}$ At 725 (emphasis added).

${ }^{187}$ At 723 (emphasis added).
} 
photograph is taken with skill and effort from the photographer, and involves "arranging and disposing the light and shade, [and] suggesting and evoking the desired expression", as stated in Burrow-Giles Lithographic Co v Sarony ${ }^{188}$. Different efforts produce different photographs and therefore each photograph should be considered to be original. That also means that taking photographs of other artistic works is not considered to be making copies of the works.

The 1999 judgment of Bridgeman Art Library, Ltd $v$ Corel Corp ${ }^{189}$ provides a different point of view about photographs of artistic works. Bridgeman is a provider of reproductions of original works of art, with a large archive in "the form of large format colour transparencies and digital files"190. This case started with Bridgeman filing a lawsuit against Corel after finding out that Corel sold a CD-ROM called "Corel Professional Photos CD-ROM Masters I-VII" in the United States, the United Kingdom, and Canada. The CD-ROM contained digital images of paintings which, Bridgeman claims, "must have been copied from its transparencies and that Corel thus is infringing its copyrights in the United States, the United Kingdom and Canada". ${ }^{191}$ Bridgeman claimed that Corel had infringed its exclusive rights because: ${ }^{192}$

(1) the owners of the underlying works of art, all of which it concedes are in the public domain, strictly limit access to those works, (2) Bridgeman's transparencies of those works, from which it prepared its digital images and presumably other reproductions, are "the only authorized transparencies of some of these works of art," 12 and (3) "[b]y inference and logical conclusion, the images in Corel's CD-ROM must be copies of Bridgeman's transparencies because they have not proved legal [sic] source."

The question was then whether the said "transparencies" were protected under copyright law in the United States and therefore whether Corel had infringed Bridgeman's copyright. Following United Kingdom precedents, the United States District Court came to the conclusion that Bridgeman's colour transparencies were not original and therefore would not be copyrightable under United Kingdom law. One opinion brought up during the trial came from British Judge Hugh Laddie, who once discussed the issue of originality of photographs as follows: ${ }^{193}$

\footnotetext{
${ }^{188}$ Burrow-Giles Lithographic Co v Sarony 111 US 53.

${ }^{189}$ Bridgeman Art Library, Ltd v Corel Corp 36 F Supp 2d 191 (SDNY 1999).

${ }^{190}$ Bridgeman Art Library, Ltd v Corel Corp 25 F Supp 2d 421 (SDNY 1998) at 423.

${ }^{191}$ At 423.

192 At 424 .

${ }^{193}$ Bridgeman Art Library, Ltd v Corel Corp 36 F Supp 2d 191 (SDNY 1999) at 198. It was cited from Hugh Laddie, Peter Prescott, \& Mary Vitoria, The Modern Law of Copyright and Designs (1995) § 3.56 at 238 (emphasis added).
} 
Originality presupposes the exercise of substantial independent skill, labour, judgment and so forth. For this reason it is submitted that a person who makes a photograph merely by placing a drawing or painting on the glass of a photocopying machine and pressing the button gets no copyright at all; but he might get a copyright if he employed skill and labour in assembling the thing to be photocopied, as where he made a montage.

The District Court stated in its first judgment that "it is uncontested that Bridgeman's images are substantially exact reproductions of public domain works, albeit in a different medium"194. The Court then held: ${ }^{195}$

In Burrow-Giles Lithographic Co v. Sarony ${ }^{196}$, the Supreme Court held that photographs are "writings" within the meaning of the Copyright Clause and that the particular portrait at issue in that case was sufficiently original -- by virtue of its pose, arrangement of accessories in the photograph, and lighting and the expression the photographer evoked -- to be subject to copyright. The Court, however, declined to decide whether "the ordinary production of a photograph" invariably satisfies the originality requirement.

As the Court believed that there was no suggestion that the reproductions that Bridgeman made varied significantly from the original works, the change of medium from paintings to photographs was considered to be "immaterial", and therefore the images owned by Bridgeman should not have their own copyright protection. ${ }^{197}$ Based on the reasons mentioned above, the Court ruled that Bridgeman's transparencies, which were not copyrightable under British law, were not copyrightable under the United States Law. ${ }^{198}$

A related conclusion based on Bridgeman Art Library, Ltd v Corel Corp ${ }^{199}$ was that photographs of artistic works should not be protected under copyright. However, that conclusion was not related to the depicted artistic works, but imore related to what was believed to be "original photographic works". Though the paintings that were discussed in that case were already in the public domain, because the District Court failed to see the originality of Bridgeman's photographs in the form of transparencies the court concluded that the photographs should not be protected. In other words, the protection granted for photographs of artistic works was different to the protection

\footnotetext{
${ }^{194}$ Bridgeman Art Library, Ltd v Corel Corp 25 F Supp 2d 421 (SDNY 1998) at 426. Also mentioned in Bridgeman Art Library, Ltd v Corel Corp 36 F Supp 2d 191 (SDNY 1999) at 199.

195 At 195 (emphasis added).

${ }^{196}$ Burrow-Giles Lithographic Co v Sarony 111 US 53.

${ }^{197}$ Bridgeman Art Library, Ltd v Corel Corp 36 F Supp 2d 191 (SDNY 1999) at 199.

${ }^{198}$ At 200.

${ }^{199}$ Bridgeman Art Library, Ltd v Corel Corp 36 F Supp 2d 191 (SDNY 1999).
} 
granted to the artistic depicted in the photographs. The protections were completely unrelated and not dependent on one another.

Another case that is related to photographs of artistic works is AntiquesPortfolio.com $v$ Rodney Fitch ${ }^{200}$. This case was heard by the High Court in London, and addressed the issue of whether photographs of three-dimensional antiques could be given copyright protection. Judge Neuberger expressed the view that the angle at which a picture was taken, and the lighting and positioning of an object were all matters of aesthetic and commercial judgement. Though the judge had no occasion to consider reproductions of two-dimensional objects, he seemed to imply that the same concept would apply to them: ${ }^{201}$

... it may well be that, if the photographer in such a case could show that he had in fact used some degree of skill and care in taking the photograph, he could claim originality in, and, therefore, intellectual property rights in respect of, such a photograph.

The case is very much related to the arguments in Burrow-Giles Lithographic Co $v$ Sarony $^{202}$. Based on AntiquesPortfolio.com $v$ Rodney Fitch ${ }^{203}$, photographs of copyright-protected artistic works should gain their own copyright protection. Photographs are original because of the efforts that the photographers put into them. Therefore, any photographs of artistic works should be recognised as original artistic works and should gain copyright protection, without the question of whether the depicted works are still under copyright protection or already in the public domain having to be considered. As photographs are considered to be original artistic works, the photographers should be able to exercise moral rights and also exclusive rights over them, including the right to gain commercial advantage from them.

There is no internationally-recognised measure by which to decide whether photographs are original. Based on the previously mentioned cases, it can be concluded that even photographs of copyright-protected artistic works can be considered original as long as it can be proven that the photographers have made efforts in "arranging and disposing the light and shade, [and] suggesting and evoking the desired expression" 204 in taking such photographs. Recital 16 and art 6 of the

\footnotetext{
${ }^{200}$ AntiquesPortfolio.com v Rodney Fitch [2001] ECDR 5 (2000).

${ }^{201}$ At 34. As referred to in Bryce Clayton Newell "Independent Creation and Originality in the Age of Imitated Reality: A Comparative Analysis of Copyright and Database Protection for Digital Models of Real People" (2010) 6 Brigham Young University International Law \& Management Review 93 at 120. ${ }^{202}$ Burrow-Giles Lithographic Co v Sarony 111 US 53.

${ }^{203}$ AntiquesPortfolio.com v Rodney Fitch [2001] ECDR 5 (2000).

${ }^{204}$ Burrow-Giles Lithographic Co v Sarony 111 US 53 at 54.
} 
Directive 2006/116/EC of the European Parliament and of the Council also concerns the originality of photographs. The recital stated that original photographs are protected under the Berne Convention and are the "author's own intellectual creation". ${ }^{205}$ This definition is similar to the judgment of Burrow-Giles Lithographic Co $v$ Sarony $^{206}$. However, it is admitted that there is no international agreement on the definition of an original photograph. ${ }^{207}$

\section{Comparison to Photographs and the Freedom of Panorama}

In reference to the cases mentioned in the previous subchapter it is clear that copyright protection for photographs and copyright protection for the object of the photographs are different from one another and do not conflict. It also seems clear that photographs taken under the freedom of panorama should not be seen as interfering with the copyright protections attached to the depicted architectural and sculptural works. The subject of most photographs consists of other people's works, but that does not mean that the photographs are not original. There is no question that photographs of three-dimensional objects, such as buildings and sculptures, are original whether a two-dimensional work that depicts a three-dimensional work is a copy of it is still very much debatable, and therefore is not a valid reason on which to prohibit the freedom of panorama.

The fact that protection for photographs taken under the freedom of panorama is not currently being regulated or protected in most countries could potentially create a legal loophole that should be fixed to avoid any doubt about copyright protection for photographs. Otherwise, the problem will only resolve around the same issue, which is copyright infringement through the taking of photographs under the freedom of panorama, until there is no point any longer discussing the issue. Photographers put effort and creativity towards the production of photographs, including those taken under the freedom of panorama. Giving copyright protection to the photographs taken under the freedom of panorama, and treating them as a separate issue to the copyright protection for the depicted copyright-protected works, would be a fair approach.

\section{Other Issues}

As mentioned in the first chapter of this paper, there are some outstanding legal issues relating to the freedom of panorama. Besides the issues already mentioned, there are

\footnotetext{
${ }^{205}$ Mireille van Eechoud and others Harmonizing European Copyright Law: The Challenges of Better Lawmaking (Kluwer Law International, Alphen aan den Rijn, 2009) at 35.

${ }^{206}$ Burrow-Giles Lithographic Co v Sarony 111 US 53.

${ }^{207}$ Eechoud and others, above n 205.
} 
also issues about conflict of laws, limitations on architects' and sculptors' exclusive rights, and international protection for the freedom of panorama. Copyright protection is often attached to the nationality of the authors of copyright-protected works. That can create an issue in determining which national law should prevail in relation to the protection for the freedom of panorama. Protection for the freedom of panorama is available in the United States, New Zealand, and Indonesia, but the freedom is provided for differently. Legal problems, or conflict of laws, may arise as to which country's copyright law prevails to resolve allegation of copyright infringement related to the act of taking photographs of architectural and sculptural works, and the right to commercialise the photographs. Should the need to provide a minimum protection for this freedom prevail, the provision for a minimum protection should be included in an international copyright treaty?

\section{A Conflict of Laws}

The principle of lex loci protectionis is universally recognised to be the base of copyright protection. This principle means that intellectual property rights are governed by the law of the country whose territory protection is claimed for example, where the registration is made. This principle is also called the territoriality principle. ${ }^{208}$ Aside from the territoriality principle, there is also the principle of lex origins, which means the governing law for a copyright-protected work is the law of the country of origin.

There are several criteria for determining the country of origin of a work. The country of origin may be the country where the work has been made available to the public, the country where the work was created, or the country in which the author is a citizen. ${ }^{209}$ The Berne Convention protects authors "who are nationals of one of the countries of the Union" 210 and "who are not nationals of one of the countries of the Union if their works first published ${ }^{211}$ in one of the countries of the Union" ${ }^{, 212}$.

Although the Berne Convention guarantees copyright protection for authors of the protected works, the national law of the country of origin of the works has the right to

\footnotetext{
${ }^{208}$ Eckart Gottschalk "The Law applicable to Intellectual Property Rights: is the Lex loci Protectionis a Pertinent Choice-of-Law Approach?” in Eckart Gottschalk, Ralf Michaels, Giesela Ruhl, and Jan von Hein Conflict of Laws in a Globalized World (Cambridge University Press, New York, 2007) at 186.

${ }^{209}$ At 188. Article 5 of the Berne Convention.

${ }^{210}$ Paris Act 1971, art 3(1)(a).

${ }^{211}$ Article 3(3) stated that "the expression "published works" means works published with the consent of their authors, whatever may be the means of manufacture of the copies, provided that the availability of such copies has been such as to satisfy the reasonable requirements of the public, having regard to the nature of the work ...".

${ }^{212}$ Article 3(1)(b).
} 
determine to what extent the copyright of the works is protected. ${ }^{213}$ Article 5(4) of the Berne Convention states that the country of origin should be determined by the following conditions: ${ }^{214}$

(a) in the case of works first published in a country of the Union, that country; in the case of works published simultaneously in several countries of the Union which grant different terms of protection, the country whose legislation grants the shortest term of protection;

(b) in the case of works published simultaneously in a country outside the Union and in a country of the Union, the latter country;

(c) in the case of unpublished works or of works first published in a country outside the Union, without simultaneous publication in a country of the Union, the country of the Union of which the author is a national, provided that:

(i) when these are cinematographic works the maker of which has his headquarters or his habitual residence in a country of the Union, the country of origin shall be that country, and

(ii) when these are works of architecture erected in a country of the Union or other artistic works incorporated in a building or other structure located in a country of the Union, the country of origin shall be that country.

The Berne Convention does not just give obligation the "country of origin" to protect literary and artistic works, but also grant national treatment. This is evident in art 5(1), 5 (3), and 6 of the Berne Convention. To be protected under the copyright law of a country, a work should meet the criteria of a protected work. After looking at how copyright laws in the United States, New Zealand, and Indonesia protect the freedom of panorama, including its exceptions and limitations, this paper makes a more general comparison between the three countries about how literary and artistic works can be protected within those countries, to see whether there is a conflict of laws in relation to the protection for photographs taken under the freedom of panorama.

\section{$1 \quad$ Country of Origin of Works}

Copyright protection could be granted without the registration of literary and artistic works. $^{215}$ To be granted copyright protection in a country, one of the requirements is that the literary or artistic work should originate from that country, or that the author

\footnotetext{
${ }^{213}$ Article 5(1) and 5(2).

${ }^{214}$ Article 5(4).

${ }^{215}$ Copyright laws in United States, New Zealand, and Indonesia stated that copyright of unpublished works, which are also not yet registered, are also protected under certain circumstances, such as "all the authors of the work are nationals, domiciliaries [sic], or habitual reside" of the country. See Copyright Act 17 USC $\S \S 101$ and 104(a), Copyright Act 1994, ss 2 and 18, and Indonesian Copyright Law 2002, art 76 letter a. These provisions are in line with Berne Convention which does not require registration to give copyright protection.
} 
be a citizen in, or a resident of, it. However, each country has its own provisions determining whether its law gives copyright protection over a particular literary or artistic work. This part of the first subchapter explains how copyright laws in the United States, New Zealand, and Indonesia see literary and artistic works as having originated from those countries.

\section{(a) United States}

To determine which country's copyright law prevails over other countries' copyright law and gives protection over protected works under the Berne Convention, it is first necessary to examine which country is seen to be the country of origin of them. In the United States, for the purpose of registration under Title 17 USC $\S 411$, a work is protected under Title 17 USC if the work is considered to be a "United States work", which a work is under the following circumstances: ${ }^{216}$

(1) in the case of a published $d^{217}$ work, the work is first published-

(A) in the United States;

(B) simultaneously in the United States and another treaty party or parties, whose law grants a term of copyright protection that is the same as or longer than the term provided in the United States;

(C) simultaneously in the United States and a foreign nation that is not a treaty party; or

(D) in a foreign nation that is not a treaty party, and all of the authors of the work are nationals, domiciliaries [sic], or habitual residents of, or in the case of an audiovisual [sic] work legal entities with headquarters in, the United States;

(2) in the case of an unpublished work $^{218}$, all the authors of the work are nationals, domiciliaries [sic], or habitual residents of the United States, or, in the case of an unpublished audiovisual [sic] work, all the authors are legal entities with headquarters in the United States; or

(3) in the case of a pictorial, graphic, or sculptural work incorporated in a building or structure, the building or structure is located in the United States.

\footnotetext{
${ }^{216}$ Copyright Act 17 USC $\$ 101$ (emphasis added).

${ }^{217}$ Copyright Act 17 USC $\S 101$ defines publication as "the distribution of copies or phonorecords [sic] of a work to the public by sale or other transfer of ownership, or by rental, lease, or lending. The offering to distribute copies or phonorecords [sic] to a group of persons for purposes of further distribution, public performance, or public display, constitutes publication. A public performance or display of a work does not of itself constitute publication".

218 This provision is also mentioned in Copyright Act 17 USC $\S 104(\mathrm{a})$, where Copyright Act 17 USC is applicable to protect unpublished original works, compilations, and derivative works "without regard to the nationality or domicile of the author".
} 
For a literary or artistic publication to be protected in the United States based on its country of origin, the works are only protected if: ${ }^{219}$

(1) on the date of first publication, one or more of the authors is a national or domiciliary of the United States, or is a national, domiciliary, or sovereign authority of a treaty party, or is a stateless person, wherever that person maybe domiciled; or (2) the work is first published in the United States or in a foreign nation that on the date of first publication, is a treaty party; or

(3) the work is a sound recording that was first fixed in a treaty party; or

(4) the work is a pictorial, graphic, or sculptural work that is incorporated in a building or other structure, or an architectural work that is embodied in a building and the building or structure is located in the United States or a treaty party; or

(5) the work is first published by the United Nations or any of its specialized agencies, or by the Organization of American States; or

(6) the work comes within the scope of a Presidential proclamation. ...

The provision above is in line with art 3(1)(a) of the Berne Convention. ${ }^{220}$ If a literary or artistic work, whether it has been published or not, satisfied one of the criteria above, then the work will be considered to be a United States work, and will therefore be protected under the Title 17 USC. Otherwise, the work may need to refer to other countries' copyright laws for its protection.

Literary and artistic works are protected under the New Zealand Copyright Act 1994 if the works qualify. The New Zealand Copyright Act 1994 provides the following qualifications: ${ }^{221}$

(1) A work qualifies for copyright if the author is, at the material time ${ }^{222}$,-

\footnotetext{
${ }^{219}$ Copyright Act 17 USC $\$ 104(b)$.

${ }^{220}$ Though the provisions Copyright Act 17 USC that are referred to in this paper are in line with Berne Convention, Copyright Act 17 USC $\S 104(c)$ actually puts a limit on the applicability of the Berne Convention in accordance with its applicability over copyright-protected works. The provision stated that "no right or interest in a work eligible for protection under this title may be claimed by virtue of, or in reliance upon, the provisions of the Berne Convention, or the adherence of the United States thereto. Any rights in a work eligible for protection under this title that derive from this title, other Federal or State statutes, or the common law, shall not be expanded or reduced by virtue of, or in reliance upon, the provisions of the Berne Convention, or the adherence of the United States thereto".

${ }^{221}$ Section 18 (emphasis added).

${ }^{222}$ Section 1. In relation to a literary, dramatic, musical, or artistic work, "material time" means the following definition:

"(i)in the case of an unpublished work, when the work is made or, if the making of the work extends over a period, a substantial part of that period; and

(ii)in the case of a published work, when the work is first published or, if the author has died before that time, immediately before his or her death".
} 
(a) a New Zealand citizen; or

(b) an individual domiciled or resident in New Zealand; or

(c) a body incorporated under the law of New Zealand.

(2) A work qualifies for copyright if the author is, at the material time,-

(a) a citizen or subject of a prescribed foreign country; or

(b) an individual domiciled or resident in a prescribed foreign country; or

(c) a body incorporated under the law of a prescribed foreign country.

In respect of country of origin, to be protected a work must be published first in New Zealand or in a "prescribed foreign country". ${ }^{223}$ In relation to that provision the New Zealand Copyright Act 1994 also defines publication and commercial publications differently. The term "publication" in general terms means "the issue of copies of the work to the public" $" 224$. However, in the case of a literary, dramatic, musical, or artistic work, the meaning of publication includes the act of "making it available to the public by means of an electronic retrieval system"225. For architectural works, the Act provides that "construction of the building shall be treated as equivalent to publication of the work" 226 . The difference between the definition of publication and commercial publication under the Act is in the condition where the issue of copies is "made in advance of the receipt of orders" 227 .

(c) Indonesia

Indonesian Copyright Law 2002 applies to "all works"228 made by Indonesian citizens, residents, and legal entities without considering whether the works are already registered, published, or not yet published. ${ }^{229}$ The other conditions for works to be protected under the Law are as follows: ${ }^{230}$

\footnotetext{
${ }^{223}$ Copyright Act 1994, s 2. This section defines "prescribed foreign country" as any country, other than New Zealand, that is included under section 230 about "application to convention countries" or that is declared by Order in Council made under section 232 about "application of Act (other than Part 9) to other entities". See also s 19.

${ }^{224}$ Section 10(1)(a).

225 Section $10(1)(\mathrm{b})$.

${ }^{226}$ Section 10(2). This protection is wider than what is mandated by art 3(3) of the Berne Convention, which stated that "the construction of a work of architecture shall not constitute publication".

${ }^{227}$ Section 11(a).

${ }^{228}$ Indonesian Copyright Law 2002, art 1 no 3. "Work shall mean any result of works of an Author, which shows originality in the field of science, arts and literature".

229 Article 76 letter a. The Elucidation of the Law for this provision does not provide further explanation.

${ }^{230}$ Article 76 letter b and c (emphasis added).
} 
b. all works of any non-Indonesian citizens, non-Indonesian residents and nonIndonesian legal entities that are published ${ }^{231}$ for the first time in Indonesia;

c. all works of any non -Indonesian citizens, non-Indonesian residents and nonIndonesian legal entities, provided that:

(i) their country has bilateral agreements on the protection of Copyright with the Republic of Indonesia;

(ii) their country and the Republic of Indonesia are parties or member countries of the same multilateral agreement on the protection of Copyright.

This provision is not as complicated as Title 17 USC or the New Zealand Copyright Act 1994, both of which have more specific provisions to regulate different kinds of copyright-protected works. Article 76 of the Law does not make the distinction of "all works" except in regard to publication.

\section{Hypothetical Case}

A hypothetical case that could be related to the protection of the freedom of panorama concerns the display of artistic works other than buildings and sculptures in public places. A mural is an artistic work, a "drawing" that uses walls on a permanent structure as its medium of expression. If a mural is made on the wall of a building, and the mural is permanently situated and visible in a public place, a question may arise as to whether others have the freedom to take photographs of the mural in the same way that they have the freedom to take photographs of the building itself under the freedom of panorama.

\section{(a) The Case}

The hypothetical case is about an individual called "AB", an Indonesian who has obtained a green card and residency in the United States. AB travelled to New Zealand and spotted an interesting mural made by "CD" on the wall of the National Library. $\mathrm{AB}$ took a photograph of the mural without gaining prior consent from $\mathrm{CD}$ then put the photograph up for exhibition in the United States with his name as the author of the photograph. Later, he sold the photograph in New Zealand. CD would like to know if his exclusive rights have been violated by $\mathrm{AB}$. The case will be viewed according to the copyright laws of the United States, New Zealand, and Indonesia respectively, under the assumption that the courts in the aforementioned countries have jurisdiction to proceed to this case, to determine whether $A B$ has the

\footnotetext{
${ }^{231}$ Article 1 no 5. "Publication shall mean the reading, broadcasting, exhibition, sale, distribution or dissemination of a Work, by utilising [sic] whatever means including the Internet, or by any manner so that such Work is capable of being read, heard or seen by any other person".
} 
right to take photographs of the mural, to be acknowledged as the author of the photograph, and to gain commercial advantage from the photograph.

\section{Copyright Protection from Title 17 USC}

Based on Title 17 USC, because the photograph was firstly published in the United States, the photograph would be protected under Title 17 USC $\S 101$ as a "United States work". Taking photographs of architectural works is also allowed under Title 17 USC $\S 120$, where the act is not considered to be a copyright infringement and the resultant work is protected by its own copyright.

Based on the provisions referred to above, and also in reference to Burrow-Giles Lithographic Co v Sarony ${ }^{232}$ and Graves' Case ${ }^{233}$, AB's taking of the photograph of the wall of the National Library with CD's mural on it would be a copyright infringement, and AB's photograph would be protected under Title 17 USC. If CD filed a lawsuit against $A B$ 's photograph of his mural, then it would most likely be most unsuccessful, as $\mathrm{AB}$ owns copyright protection over the photograph and is therefore able to exhibit and sell it.

\section{(c) Copyright Protection from New Zealand Copyright Act 1994}

Under s 19 of the New Zealand Copyright Act 1994, the photograph might be granted copyright protection under the Act if it was first published in a "prescribed foreign country", which was the United States. ${ }^{234}$ According to s 73 of the Act, taking photographs of buildings and other works that are permanently situated in public places such as sculptures, models for buildings, or works of artistic craftsmanship, does not infringe the copyright of the depicted works. It is unclear what might fall under "works of artistic craftsmanship" "235, but the mural on the wall of the National Library was being made and placed in a public place though it might not be permanently situated there. $^{236}$

Before reviewing the case from the perspective of the New Zealand Copyright Act 1994 and in order to get a clearer idea what "works of artistic craftsmanship" are, it is

\footnotetext{
${ }^{232}$ Burrow-Giles Lithographic Co v Sarony 111 US 53.

${ }^{233}$ Graves' Case [1869] LR 4 QB 715.

${ }^{234}$ Copyright Act 1994, s 230(1)(a).

${ }^{235}$ Section 2. The provision could be read as "works of artistic craftsmanship are artistic works which are not falling within the category of a graphic work, photograph, sculpture, collage, or model, irrespective of artistic quality, or a work of architecture".

236 There is no definition of the wording "permanent". If this wording is seen from how easy a copyright-protected work could be removed from a public place, the mural might not be permanent as it could be easily changed into other design of mural or removed completely.
} 
worth looking at the discussion in Bonz Group Pty Ltd $v$ Cooke $e^{237}$. In that case, Tipping $\mathbf{J}$ from the Christchurch High Court quoted Viscount Dilhorne to the effect that a work of artistic craftsmanship was something made by hand and not massproduced. The Judge then stated that he believed a work of artistic craftsmanship should present an artistic quality and should be made by an author who was "both a craftsman and an artist" ${ }^{238}$. Tipping $\mathbf{J}$ also defined a craftsman as "a person who makes something in a skilful way and takes justified pride in their workmanship". $\mathrm{He}$ defined an artist as "a person with creative ability who produces something which has aesthetic appeal", and someone who can "impart a sufficient degree of skill, experience, and effort in creating the ultimate product" of artistic craftsmanship. ${ }^{239}$

To return to the discussion about the hypothetical case, CD's mural on the wall of National Library would be protected under the Act as a form of artistic work, which is "a graphic work" 240 . If the mural was constantly altered and was not attached to the National Library building, then AB's act of taking the photograph might be seen to have infringed CD's copyright. That the photograph could only be protected under the Act if the mural was permanently attached to the National Library building means it falls under the category of "an artistic work permanently situated in public places". In other words, the photograph was taken under the freedom of panorama and was protected under s 73 of the Act. However, if $\mathrm{AB}$ wants to publish the photograph, $\mathrm{CD}$ has the right to be acknowledged as the author of the mural, a right that is protected under s 94(6) of the Act.

If the mural is proven to be permanently situated in a public place, then $\mathrm{AB}$ also has the right to commercialise the photograph, as photographers are allowed to sell photographs taken under the freedom of panorama. In reference to Radford $v$ Hallenstein Bros Ltd ${ }^{241}$, Judge Keane of the District Court Auckland stated that s 73 of the Act "sets out to allow members of the public ... to copy in two-dimensional sculptures permanently in the public domain and even for profit" ${ }^{242}$. In this case,

\footnotetext{
${ }^{237}$ Bonz Group Pty Ltd v Cooke [1994] 3 NZLR 216. This case is about Bonz Group, a company which manufactured and sold hand-knitted woollen garments in Australia and New Zealand, filed a copyright infringement suit against Cooke after she started manufacturing and selling hand-knitted garments through selected outlets. Bonz Group believed that Cooke's garments "were too similar to their own" and sued Cooke for copyright infringement of "works of artistic craftsmanship".

238 At 31. Graham provides the same argument and this should be shown on "the design and the execution of the work". He also adds that "[t]here must be demonstrated creative ability and aesthetic appeal, as well as skilful workmanship”. See Graham, above n 124, at 382.

${ }^{239}$ At 31 .

${ }^{240}$ Copyright Act 1994, s 2.

${ }^{241}$ Radford v Hallenstein Bros Ltd [2009] DCR 907.

${ }^{242}$ Radford $v$ Hallenstein Bros Ltd HC Auckland CIV-2006-404-4881 (22 February 2007) at 35 (emphasis added).
} 
"sculptures" could logically be replaced with "works permanently situated in public places".

(d) Copyright Protection from Indonesian Copyright Law 2002

The photograph would be protected under the Indonesian Copyright Law 2002 because the photograph was made by an Indonesian citizen. ${ }^{243}$ As photographs are protected without dispute, even if the objects of the photographs are copyrightprotected works, AB's photograph of CD's mural could be protected under the Law. Therefore, copyright protection for the photograph is separate from copyright protection for the mural.

\section{(e) Possibility for Conflict of Laws}

Conflict of laws may appear in the field of copyright law where there are different provisions related to certain legal issues-for example, in the case of infringement and ownership. For the hypothetical case above, it might be that the work would not be protected in the United States because it is being sold in New Zealand, and the United States court might feel that it is more appropriate to use the New Zealand Copyright Act 1994 to determine whether CD's exclusive rights have been violated by AB. At the same time, a New Zealand court may feel that Title 17 USC is more appropriate because the work was firstly published in the United States. Based on the closest connection theory, because the photographer is a United States resident and the work was first published in the United States, the most appropriate copyright law to govern the hypothetical is Title 17 USC.

Copyright protection is often attached to the nationality of the authors of copyrightprotected works. That creates an issue for those who want to determine which national law should prevail in relation to protection for the freedom of panorama. Protection for the freedom of panorama is available in the United States, New Zealand, and Indonesia, but those protections are different. If there is a need to provide a minimum protection for this freedom, then the provision for a minimum protection should be included in an international copyright treaty.

\section{B International Recognition and Protection for Photographs Taken under the Freedom of Panorama}

\footnotetext{
${ }^{243}$ Indonesian Copyright Law 2002, art 76 letter a.
} 
Photographs taken under the freedom of panorama should not be seen as copies of the depicted works, as they are of a different medium and are three-dimensional and twodimensional respectively. It is therefore impossible to create copies of buildings and sculptures by taking photograph of them. In terms of deciding whether such photographs should be recognised as original, adaptations or derivative works, there is no set way to determine whether photographs taken under the freedom of panorama are original works, adaptations, or derivative works, and therefore they are eligible for copyright protection, or they are only copies of the depicted works. Article 2(3) of the Berne Convention provides that: ${ }^{244}$

Translations, adaptations, arrangements of music and other alterations of a literary or artistic work shall be protected as original works without prejudice to the copyright in the original work.

Based on the provision above, where it is applicable that photographs taken under the freedom of panorama are acknowledged as adaptations or derivative works, the Berne Convention provides that the photographs should be protected in the same way as original works.

\section{Fair Practice and the Freedom of Panorama}

\section{$1 \quad$ Fair Practice Provisions in Berne Convention and Its Amendments}

The provision on fair practice was provided in the Berne Convention (1886) and constantly included in its amendments. Art 8 of the Berne Convention (1886) stated as follows: ${ }^{245}$

As regards the liberty of extracting portions from literary or artistic works for use in publications destined for educational or scientific purposes, or for chrestomathies, the effect of the legislation of the countries of the Union, and of special arrangements existing or to be concluded between them, is not affected by the present Convention.

The said provision was adopted as art 10 of the Berlin Act (1908) and afterwards adopted as art 10 of the Rome Act (1928). Though this provision lasted for more than 40 years, at Brussels Conference of 1948 the parties to the Conference were concerned about fair practice as "the question of borrowings from known works has always been a source of abuses" ${ }^{\text {246 }}$. The parties to the Conference agreed that short quotations from newspaper articles and periodicals were lawful and that quotations

\footnotetext{
${ }^{244}$ Paris Act 1971, art 2(3).

${ }^{245}$ Berne Convention 1886, art 8.

${ }^{246}$ Records of the Brussels Conference of 1948, above n 56.
} 
should always be accompanied by an acknowledgement of the source and the name of the author, but that the right to take excerpts from literary and artistic works for teaching was a matter to be decide in the legislation in the countries of the Union. These considerations resulted in art 10 of the Brussels Act (1948) as follows: ${ }^{247}$

(1) It shall be permissible in all the countries of the Union to make short quotations from newspaper articles and periodicals, as well as to include them in press summaries.

(2) The right to include excerpts from literary or artistic works in educational or scientific publications, or in chrestomathies, in so far as this inclusion is justified by its purpose, shall be a matter for legislation in the countries of the Union, and for special Arrangements existing or to be concluded between them.

(3) Quotations and excerpts shall be accompanied by an acknowledgment of the source and by the name of the author, if his name appears thereon.

At the Stockholm Conference of 1967, it was proposed that the rule on quotations contained in art 10(1) of the Brussels Act (1948) be broadened so to make short quotations as a general rule applying to all categories of works, while the main content in art 10(2) and 10(3) of the Brussels Act (1948) remained unchanged. The parties of the Conference agreed to the proposed change and the provision in art 10 of the Stockholm Act (1967) remains in art 10 of the Paris Act (1971) as follows: ${ }^{248}$

(1) It shall be permissible to make quotations from a work which has already been lawfully made available to the public, provided that their making is compatible with fair practice, and their extent does not exceed that justified by the purpose, including quotations from newspaper articles and periodicals in the form of press summaries.

(2) It shall be a matter for legislation in the countries of the Union, and for special agreements existing or to be concluded between them, to permit the utilization, to the extent justified by the purpose, of literary or artistic works by way of illustration in publications, broadcasts or sound or visual recordings for teaching, provided such utilization is compatible with fair practice.

(3) Where use is made of works in accordance with the preceding paragraphs of this Article, mention shall be made of the source, and of the name of the author if it appears thereon.

\section{$2 \quad$ Fair Practice in Several Countries}

"Fair practice" limitations on the exclusive rights to reproduce or authorise others to reproduce copyright-protected works. Under the doctrine of fair use, people can reproduce copyright-protected works without permission from their copyright owners and yet,

\footnotetext{
${ }^{247}$ Brussels Act 1948, art 10.

${ }^{248}$ Paris Act 1971, art 10.

249 The wordings "fair practice" refers to the provisions in the Berne Convention (1886) and its amendments.

${ }^{250}$ The wordings "fair use" refers to the fair practice provisions in Copyright Law of the United States.
} 
such reproductions are not considered to be copyright infringement. Title 17 USC $\S$ 107 contains a list of the various purposes for which the reproduction of a particular work may be considered fair, such as criticism, comment, news reporting, teaching, scholarship, and research. This Section also sets out the factors to be considered in determining whether or not a particular use is fair: ${ }^{251}$

(1) the purpose and character of the use, including whether such use is of a commercial nature or is for nonprofit educational purposes;

(2) the nature of the copyrighted work;

(3) the amount and substantiality of the portion used in relation to the copyrighted work as a whole; and

(4) the effect of the use upon the potential market for or value of the copyrighted work.

In New Zealand, a "fair dealing" 252 provision can be found in s 42 and 43 of the Copyright Act. This provision allows some copying for private study, research, criticism, review, and news reporting without that copying being considered as copyright infringement. Unlike the doctrine of fair use in the United States, fair dealing cannot apply to any act which does not fall within one of the strictly limited categories. To determine whether copying constitutes fair dealing for the purposes of research or private study, the Court should observe the following criteria: ${ }^{253}$

(a) the purpose of the copying; and

(b) the nature of the work copied; and

(c) whether the work could have been obtained within a reasonable time at an ordinary commercial price; and

(d) the effect of the copying on the potential market for, or value of, the work; and

(e) where part of a work is copied, the amount and substantiality of the part copied taken in relation to the whole work.

Similar provisions related to fair practice are also available in arts 14 and 15 of the Indonesian Copyright Law 2002, and they allow for a broader spectrum of use than "fair use" in the United States and fair dealing in New Zealand. In Indonesia, fair practice includes the use of copyright-protected works for the purpose of education, news reporting, criticism, and review. ${ }^{254}$ Although the terminology that is used and the categories of fair practice more limited, fair practice provisions in the copyright laws of the United States, New Zealand, and Indonesia do not include personal and commercial use of copyright-protected works.

\footnotetext{
${ }^{251}$ Copyright Law 17 USC $§ 107$.

${ }^{252}$ The wordings "fair use" refers to the fair practice provisions in Copyright Act of New Zealand.

${ }^{253}$ Copyright Act, art 43.

${ }^{254}$ Copyright Law (Indonesia), art 15.
} 
There is no reference to copyright protection for photographs of copyright-protected works in the Paris Act (1971) and it is not available in some countries of the Union. The debate about this issue might culminate in being like the initial debate on international protection for photographic works as artistic works. If taking photographs under the freedom of panorama can only be internationally protected when the photographs are also taken under the doctrine of fair practice, then the photographers will not have the right to commercialise photographs taken under the freedom of panorama. Wider protection for photographs taken under the freedom of panorama such as the provisions available in the United States and New Zealand, where the photographers are given copyright protection including the right to commercialise the photographs, could only be referred to in domestic law.

\section{No Exceptions or Limitations to Moral Rights of Architects and Sculptors}

Moral rights are attached to the authors of literary and artistic works. ${ }^{255}$ Limitations and exceptions to the rights within copyright protection differ from country to country, but the protection for moral rights is applied in the United States, New Zealand, and Indonesia at the same time as the applicability of copyright protection for photographs taken under the freedom of panorama in the three mentioned countries. In the United States, authors of architectural works do not get protection for their moral rights as architectural works is not one of works of visual art. ${ }^{256}$ This means that Title 17 USC $\S 120$ is not in conflict with moral rights of the architects, which is protected differently in New Zealand and Indonesia. In Title 17 USC § 120, though it is clearly stated that taking photographs of architectural works will not infringe the copyright of the works, it is not stated whether the photographs should be considered as original works or derivative works. However, both types of works are protected equally under Title 17 USC $\S 102$ and 103, and copyright protection over the photographs does not make a limitation or an exception for copyright protection over the depicted works.

\footnotetext{
${ }^{255}$ Article 6bis of the Paris Act 1971 stated that "the author shall have the right to claim authorship of the work". Article 94 of the New Zealand Copyright Law 1994 and fifth paragraph of the Preamble in Elucidation of Indonesian Copyright Law 2002 provide the provisions that are in line with art 6bis of the Paris Act 1971, but Title 17 USC $\$ 106$ A only provides protection of moral rights limited to authors of works of visual art. However, the World Trade Organization overview on the Agreement on Trade Related Aspects of Intellectual Property Rights stated that "[countries of the Union] do not have rights or obligations under the TRIPS Agreement in respect of the rights conferred under Article 6bis of that Convention, i.e. the moral rights". See World Trade Organization "Overview: the TRIPS Agreement" <http://www.wto.org/english/tratop_e/trips_e/intel2_e.htm>.

${ }^{256}$ Copyright Act 17 USC $\$ 106 \mathrm{~A}$ and 120.
} 
Copyright protection for photographs under art 73 of the New Zealand Copyright Act 1994 is given not to limit exclusive rights of the authors of works that are permanently situated in public places, which include architects and sculptors, but to protect photographers from copyright infringement issues. In Indonesia, photographs of copyright-protected works are protected as "original" photographs and they are not seen as infringing copyright of the depicted works.

\section{Conclusions}

There is no exception or limitation on which kind of photographs are being protected under copyright law, whether it is of copyright-protected works, based on the Berne Convention. This means that copyright protection for photographs taken under the freedom of panorama, which this paper refers to as the right to take photographs of copyright-protected works that are permanently situated in public places without having to gain prior consent from the authors of the works, is not prohibited under the Berne Convention. This protection also exists in practice within copyright laws in the United States, New Zealand, and Indonesia. There is also no limitation on taking photographs of copyright-protected works under the Berne Convention. This means that the photographs taken under the freedom of panorama should gain copyright protection in the same sense as "original" photographs because the photographers have put efforts in the making of the photographs, and the photographers are entitled to exercise their exclusive rights and moral rights over such photographs.

To add to the conclusions above on how photographs taken under the freedom of panorama should be protected, the protection should be separated from the object of the photographs and therefore it is closely related to the provisions related to the making of derivative works as stated in Title 17 USC. In making of adaptation or derivative works, the authors of the works are entitled to get "sole" copyright protection over their works and this protection is separated from the "original" works they based their works on. The protection would not intervene copyright protection over the "original" works which means that the architects and sculptors can still exercise their exclusive rights to the possible extent. Copyright protection for adaptation or derivative works is not considered as limiting the "original" authors' rights to exercise their exclusive rights and therefore protection for the photographs taken under the freedom of panorama should not be seen as limiting the architects and sculptors' rights.

Taking photographs under the freedom of panorama under the copyright laws in the United States and New Zealand is considered as making original works and this point of view is actually in line with how photographs of public domain works are 
protected. Photographs of public domain works obtain copyright protection regardless of the depicted works are no longer protected, which means that there is separation between the copyright of the depicted works from the copyright of the photographs. This also means that copyright holders of such photographs are allowed to gain commercial advantage from the photographs. In this sense, photographs taken under the freedom of panorama should obtain its copyright protection because the photographs are new artistic works and therefore its protection should not be linked to the depicted copyright-protected works.

If the freedom of panorama is seen as an act of reproduction, based on the three-step test, the issue of the freedom of panorama would satisfy the three required steps. For the first step in "certain special cases", the freedom of panorama is specifically related to the act of taking photographs of works permanently situated in public places, although what is covered under the word "works" differs in the United States and New Zealand. It is also a special case that taking photographs in public places should not be seen as violating architects and sculptors' rights. ${ }^{257}$

The second step requires that the freedom of panorama "does not conflict with a normal exploitation of a work". The fulfilment of this step can be seen in the sense that this freedom to take photographs does not limit what usually can be done over architectural and sculptural works by their authors. Other than that, the freedom of panorama implements copyright protection over photographs and not limiting what can be photographed or not in public places.

Finally, the third step requires the freedom of panorama to "not unreasonably prejudice the legitimate interests of the author". The freedom of panorama does not limit the architects and sculptors' ability to gain commercial advantage from their works although these were placed in public places. Other than that, the freedom of panorama merely implements copyright protection over photographs, by ensuring that there is no limitation of what can or cannot be photographed in public places.

Aside from the explanation above, the jurisdictional comparison shows that there are different protections given to the photographs taken under the freedom of panorama. Therefore, it is necessary to include the protection for the freedom of panorama in an international legal instrument for example to mention it under the Berne Convention to avoid any doubt in the protection of such photographs. This way, there will be a

\footnotetext{
${ }^{257}$ Knights, above $\mathrm{n} 11$. Christophe Geiger and others "The Three-Step Test Revisited: How to Use the Test's Flexibility" in National Copyright Law in Program on Information Justice and Intellectual Property Research Paper Series (Washington, 2013).
} 
"uniform" minimum protection that should be given by the members of the Union and this will minimise the probability of conflict of laws issues. 


\section{Bibliography}

\section{A Cases}

$1 \quad$ New Zealand

Bonz Group Pty Ltd v Cooke [1994] 3 NZLR 216.

Radford v Hallenstein Bros Ltd DC Auckland CIV-2005-004-3008, 17 July 2006.

Radford v Hallenstein Bros Ltd HC Auckland CIV-2006-404-4881, 22 February 2007.

Radford v Hallenstein Bros Ltd [2009] DCR 907.

$2 \quad$ United Kingdom

Graves' Case [1869] LR 4 QB 715.

Lucasfilm Ltd v Ainsworth [2011] All ER 257 (SC).

Shelley Films Ltd v Rex Features Ltd [1994] EMLR 134 (HC).

$3 \quad$ United States

AntiquesPortfolio.com v Rodney Fitch [2001] ECDR 5 (2000).

Bridgeman Art Library, Ltd v Corel Corp 25 F Supp 2d 421 (SDNY 1998).

Bridgeman Art Library, Ltd v Corel Corp 36 F Supp 2d 191 (SDNY 1999).

Burrow-Giles Lithographic Co v Sarony 111 US 53.

Ets-Hokin v Skky Spirits, Inc 225 F 3d 1068 (9th Cir 2000).

Gaylord v United States 85 F Cl 59 (DC Cir 2008).

Gaylord v United States 595 F 3d 1364 (DC Cir 2010).

Gaylord v United States 98 Fed Cl 389 (DC Cir 2011).

Gaylord v United States 678 F 3d 1339 (DC Cir 2012).

Martha Reyes $v$ Wyeth Pharmaceuticals, Inc 603 F Supp 2d 289 (DPR 2009).

Pagano, et al v Chas Beseler Co 234 F 963 (SD NY 1916).

The Rock and Roll Hall of Fame and Museum, Inc, et al v Gentile Productions, et al 134 F.3d 749 (6th Cir 1998).

The Rock and Roll Hall of Fame and Museum, Inc, et al v Gentile Productions, et al 71 F Supp 2d 755 (ND OH 1999).

Schrock v Learning Curve International, Inc 586 F 3d 513 (7th Cir 2009).

\section{B Legislations \\ $1 \quad$ New Zealand}

Copyright Act 1994.

2 Australia

Copyright Act 1968 (Cth). 
$3 \quad$ Indonesia

Undang-Undang tentang Hak Cipta [Law regarding Copyright] 2002.

Elucidation of Indonesian Copyright Law 2002.

$4 \quad$ Italy

Protezione del diritto d'autore e di altri diritti connessi al suo esercizio [Law for the Protection of Copyright and Neighbouring Rights] 2008.

$5 \quad$ Malaysia

Akta Hakcipta [Copyright Act] 1987.

$6 \quad$ Singapore

Copyright Act 1988.

$7 \quad$ United Kingdom

Copyright, Designs and Patents Act 1988.

$8 \quad$ United States

Copyright Law 17 (USC).

\section{International Materials}

Agreement on Trade-Related Aspects of Intellectual Property Rights (opened for signature 15 April 1994, entry into force 1 January 1995).

Berne Convention for the Protection of Literary and Artistic Works (opened for signature 9 September 1886, completed 4 May 1896).

Additional Act Amending Articles 2, 3, 5, 7, 12, and 20, of the Convention of September 9, 1886, and Numbers 1 and 4 of the Final Protocol Annexed Thereto (completed 4 May 1896).

Revised Berne Convention for the Protection of Literary and Artistic Works (opened for signature 9 September 1886, completed 20 March 1914).

International Convention for the Protection of Literary and Artistic Works (opened for signature 9 September 1886, last amended 2 June 1928).

Berne Convention for the Protection of Literary and Artistic Works (opened for signature 9 September 1886, last amended 26 June 1948).

Berne Convention for the Protection of Literary and Artistic Works (opened for signature 9 September 1886, last amended 14 July 1967).

Berne Convention for the Protection of Literary and Artistic Works (opened for signature 9 September 1886, last amended 28 September 1979, entry into force 19 November 1984). 
Directive 2001/29/EC of the European Parliament and of the Council of 22 May 2001 on the harmonisation of certain aspects of copyright and /related rights in the information society [2001] OJ L167/10.

Directive 2006/116/EC of the European Parliament and of the Council of 12 December 2006 on the term of protection of copyright and certain related rights [2006] OJ L372/12.

WIPO Copyright Treaty (opened for signature 20 December 1996, entry into force 6 March 2002).

\section{Books and Chapters in Books}

Elizabeth Adeney The Moral Rights of Authors and Performers: An International and Comparative Analysis (Oxford University Press, New York, 2006).

Graeme Austin and Laurence R Helfer Human Rights and Intellectual Property: Mapping the Global Interface (Cambridge University Press, New York, 2011).

Margreth Barrett Intellectual Property (Wolters Kluwer Law \& Business, New York, 2012).

Mireille van Eechoud and others Harmonizing European Copyright Law: The Challenges of Better Lawmaking (Kluwer Law International, Alphen aan den Rijn, 2009).

Justin Graham "New Zealand" in Ben Allgrove (ed) International Copyright Law: A Practical Global Guide (Globe Law and Business, London, 2013) 379 at 382.

Joseph Henry Beale The Conflict of Laws (Baker, Voorhis \& Co, Inc, New York, 1935).

Lionel Bently, Uma Suthersanen and Paul Torremans (ed) Global copyright: three hundred years since the Statute of Anne, from 1709 to cyberspace (Edward Elgar, Cheltenham, 2010).

James Boyle Public Domain: Enclosing the Commons of the Mind (Yale University Press, London, 2008).

William Cornish Cases and Materials on Intellectual Property (5th ed, Sweet \& Maxwell, London, 2006).

P P Craig and G de Búrca The Evolution of EU Law (Oxford University Press, Oxford, 1999).

P P Craig and G de Búrca EU Law: Text, Cases, and Materials (2nd ed, Oxford University Press, New York, 2011).

Gillian Davies Copyright and the Public Interest (VCH, New York, 1994).

Christina Dementriades Intellectual Property Issues in Commercial Transactions (Sweet \& Maxwell, London, 2008).

Estelle Derclaye and Matthias Leistner Intellectual Property Overlaps: a European Perspective (Hart Publishing, Portland, 2011).

Susy Frankel Intellectual Property in New Zealand (2nd ed, LexisNexis, Wellington, 
2011).

Kevin Garnett, Gillian Davies and Gwilym Harbottle Copinger and Skone James on Copyright (16th ed, Sweet \& Maxwell, London, 2011).

Christophe Geiger and others "The Three-Step Test Revisited: How to Use the Test's Flexibility" in National Copyright Law in Program on Information Justice and Intellectual Property Research Paper Series (Washington, 2013).

Jonathan Griffiths and Uma Suthersanen Copyright and Free Speech: Comparative and International Analyses (Oxford University Press, New York, 2005).

Jack L Goldsmith and Eric A Posner The Limits of International Law (Oxford University Press, Oxford, 2005).

Eckart Gottschalk "The Law applicable to Intellectual Property Rights: is the Lex loci Protectionis a Pertinent Choice-of-Law Approach?" in Eckart Gottschalk, Ralf Michaels, Giesela Ruhl, and Jan von Hein Conflict of Laws in A Globalized World (Cambridge University Press, New York, 2007).

James J Fawcett and Paul Torremans Intellectual Property and Private International Law (Oxford University Press, New York, 2011).

Paul Goldstein and P Bernt Hugenholtz International Copyright: Principles, Law, and Practice (Oxford University Press, New York, 2010).

Stef van Gompel Formalities in Copyright Law: An Analysis of Their History, Rationales and Possible Future (Kluwer Law International, 2011).

Roger Knights "Limitations and Exceptions under the "Three-Step-Test" and in National Legislation-Differences between the Analog and Digital Environment" in World Trade Organization Regional Workshop on Copyright and Related Rights in the Information Age (Moscow, 2001).

Tshimanga Kongolo Unsettled International Intellectual Property Issues (Wolters Kluwer Law \& Business, Austin, 2008).

Stephen P Ladas The International Protection of Literary and Artistic Property 2 vol (The Macmillan Company, New York, 1938).

D Lasok and P A Stone Conflict of Laws in the European Community (Professional, Abingdon, 1987).

Silke von Lewinski International Copyright Law and Policy (Oxford University Press, New York, 2008).

Duncan Matthews Globalising intellectual Property Rights: the TRIPs Agreement (Routledge, London, 2002).

Christina Michalos The Law of Photography and Digital Images (Sweet \& Maxwell Ltd, London, 2004).

Gary Myers Principles of Intellectual Property Law (Thomson/West, Minnesota, 2008).

Mira T Sundara Rajan Moral Rights: Principles, Practice and New Technology (Oxford University Press, New York, 2011). 
Sam Ricketson and Jane C Ginsburg International Copyright and Neighbouring Rights: The Berne Convention and Beyond 2 vol (Oxford University Press, Oxford, 2006).

Sam Ricketson and Uma Suthersanen "The Design/Copyright Overlap: Is There a Resolution?" in Neil Wilkof and Shamnad Basheer (ed) Overlapping Intellectual Property Rights (Oxford University Press, Oxford, 2012).

Jan Rosén "Copyright and freedom of expression in Sweden - private law in a constitutional context" in Paul Torremans (ed) Copyright Law: A Handbook of Contemporary Research (Edward Elgar Publishing Limited, Cheltenham, 2007).

Brad Sherman and Alain Strowel Of Authors and Origins: Essays on Copyright Law (Clarendon Press, New York, 1994).

Stephen M Stewart International Copyright and Neighbouring Rights (Butterworths, London, 1983).

Paul Sumpter Intellectual Property Law: Principles in Practice (2nd ed, CCH New Zealand Limited, Auckland, 2013).

Paul Torremans Copyright Law: A Handbook of Contemporary Research (Edward Elgar, Northampton, 2007).

David Vaver (ed) Intellectual Property Rights: Critical Concepts in Law (Routledge, London, 2006).

Sir John Norman Keates Whitford Copyright and designs law: report of the Committee to Consider the Law on Copyright and Designs (HMSO, London, 1977).

Lior Zemer The Idea of Authorship in Copyright (Ashgate Publishing Limited, Hampshire, 2007).

\section{E Journal Articles}

Bryce Clayton Newell "Independent Creation and Originality in the Age of Imitated Reality: A Comparative Analysis of Copyright and Database Protection for Digital Models of Real People" (2010) 6 Brigham Young University International Law \& Management Review 93.

Bryce Clayton Newell "Freedom of Panorama: A Comparative Look at International Restrictions on Public Photography" (2011) 44 Creighton L Rev 405.

Susan Corbett "Creative Commons Licences, the Copyright Regime and the Online Community: Is there a Fatal Disconnect?" (2011) 74 MLR 503.

Susy Frankel "Digital Copyright and Culture" (2010) 27 J Arts Mgmt \& L 140.

Justin Hughes “The Photographer's Copyright - Photograph as Art, Photograph as Database" (2012) 25 Harv J L \& Tech 327.

Mark P McKenna “The Right of Publicity and Autonomous Self-Definition” (2005) 67 U Pitt L Rev 225.

Simon Stokes "Graves' case revisited in the USA" (2000) 11 Ent L Rev 104. 


\section{F Internet Resources}

Copyright Council of New Zealand "Public domain - What does "public domain" refer to?" <http://www.copyright.org.nz>.

Joshua Benton "Wired releases images via Creative Commons, but reopens a debate on what "noncommercial" means" (8 November 2011) Nieman Journalism Lab $<$ http://www.niemanlab.org/>.

Daniel Grant "Photographs of Public Artwork by Anish Kapoor and Christo \& Jeanne-Claude: Copyright Infringement?" (May 2005) International Sculpture Center $<$ http://www.sculpture.org>.

Lesley Ellen Harris "What to do if You're Accused Of Copyright Infringement" World Intellectual Property Organization <http://www.wipo.int/>.

Peter B Hirtle "Copyright Term and the Public Domain in the United States 1 January 2013" (3 January 2013) Cornell University Copyright Information Center $<$ http://copyright.cornell.edu/ $>$.

Mike Linksvayer "Creative Commons Defining "Noncommercial": A Study of How the Online Population Understands "Noncommercial Use"” (14 September 2009) Creative Commons <http://creativecommons.org/>.

Lien Verbauwhede "Legal Pitfalls in Taking or Using Photographs of Copyright Material, Trademarks and People" (23 February 2006) World Intellectual Property Organization <http://www.wipo.int $>$.

"Records of the International Conference for the Protection of Authors' Rights: Convened in Berne, September 8 to 19, 1884" in Sam Ricketson and Jane C Ginsburg International Copyright and Neighbouring Rights: The Berne Convention and Beyond (9 December 2005) Oxford University Press <http://global.oup.com>.

"Records of the Second International Conference for the Protection of Authors' Rights: Convened in Berne, September 7 to 18, 1885" in Sam Ricketson and Jane C Ginsburg International Copyright and Neighbouring Rights: The Berne Convention and Beyond (9 December 2005) Oxford University Press <http://global.oup.com>.

"Records of the Third International Conference for the Protection of Authors' Rights: Convened in Berne, September 6 to 9, 1886" in Sam Ricketson and Jane C Ginsburg International Copyright and Neighbouring Rights: The Berne Convention and Beyond (9 December 2005) Oxford University Press <http://global.oup.com>.

"Records of the Diplomatic Conference: Convened in Paris, April 15 to May 4, 1896" in Sam Ricketson and Jane C Ginsburg International Copyright and Neighbouring Rights: The Berne Convention and Beyond (9 December 2005) Oxford University Press <http://global.oup.com>.

"Records of the Diplomatic Conference: Convened in Berlin, October 14 to November 14, 1908” in Sam Ricketson and Jane C Ginsburg International Copyright and Neighbouring Rights: The Berne Convention and Beyond (9 December 2005) Oxford University Press <http://global.oup.com>. 
"Records of the Diplomatic Conference: Convened in Rome, May 7 to June 2, 1928" in Sam Ricketson and Jane C Ginsburg International Copyright and Neighbouring Rights: The Berne Convention and Beyond (9 December 2005) Oxford University Press <http://global.oup.com>.

"Records of the Diplomatic Conference: Convened in Brussels, June 5 to 26, 1948" in Sam Ricketson and Jane C Ginsburg International Copyright and Neighbouring Rights: The Berne Convention and Beyond (9 December 2005) Oxford University Press <http://global.oup.com>.

"Records of the Intellectual Property Conference of Stockholm: June 11 to July 14, 1967 Volume II" in Sam Ricketson and Jane C Ginsburg International Copyright and Neighbouring Rights: The Berne Convention and Beyond (9 December 2005) Oxford University Press <http://global.oup.com>.

"Records of the Diplomatic Conference for the Revision of the Berne Convention: Paris, July 5 to 24, 1971" in Sam Ricketson and Jane C Ginsburg International Copyright and Neighbouring Rights: The Berne Convention and Beyond (9 December 2005) Oxford University Press <http://global.oup.com>.

United States Copyright Office "Copyright in Derivative Works and Compilations" $<$ http://www.copyright.gov>.

United States Copyright Office "Copyright Law of the United States of America and Related Laws Contained in Title 17 of the United States Code" $<$ http://www.copyright.gov/>.

“"Welcome to the Public Domain" Copyright \& Fair Use", Stanford University Libraries <http://fairuse.stanford.edu>.

World Trade Organization "Overview: the TRIPS Agreement" <http://www.wto.org>. 